\title{
Zoonotic Blood-Borne Pathogens in Non-Human Primates in the Neotropical Region: A Systematic Review
}

\author{
Gabriel Carrillo-Bilbao ${ }^{1,2,3}$, Sarah Martin-Solano ${ }^{3,4} \mathbb{D}$ and Claude Saegerman ${ }^{1, *(\mathbb{D})}$ \\ 1 Research Unit of Epidemiology and Risk Analysis Applied to Veterinary Sciences (UREAR-ULiège), \\ Fundamental and Applied Research for Animal and Health (FARAH) Center, Department of Infections and \\ Parasitic Diseases, Faculty of Veterinary Medicine, University of Liège, 4000 Liège, Belgium; \\ gabriel.carrillobilbao@doct.uliege.be \\ 2 Facultad de Filosofía y Letras y Ciencias de la Educación, Universidad Central del Ecuador, \\ 170521 Quito, Ecuador \\ 3 Instituto de Investigación en Zoonosis (CIZ), Universidad Central del Ecuador, 170521 Quito, Ecuador; \\ ssmartin@espe.edu.ec \\ 4 Grupo de Investigación en Sanidad Animal y Humana (GISAH), Carrera Ingeniería en Biotecnología, \\ Departamento de Ciencias de la Vida y la Agricultura, Universidad de las Fuerzas Armadas-ESPE, \\ 171103 Sangolquí, Ecuador \\ * Correspondence: claude.saegerman@uliege.be
}

check for updates

Citation: Carrillo-Bilbao, G.; Martin-Solano, S.; Saegerman, C. Zoonotic Blood-Borne Pathogens in Non-Human Primates in the Neotropical Region: A Systematic Review. Pathogens 2021, 10, 1009. https://doi.org/10.3390/ pathogens 10081009

Academic Editor: Andrew Taylor-Robinson

Received: 4 July 2021

Accepted: 5 August 2021

Published: 10 August 2021

Publisher's Note: MDPI stays neutral with regard to jurisdictional claims in published maps and institutional affiliations.

Copyright: (c) 2021 by the authors. Licensee MDPI, Basel, Switzerland. This article is an open access article distributed under the terms and conditions of the Creative Commons Attribution (CC BY) license (https:/ / creativecommons.org/licenses/by/ $4.0 /)$.
Abstract: Background: Understanding which non-human primates (NHPs) act as a wild reservoir for blood-borne pathogens will allow us to better understand the ecology of diseases and the role of NHPs in the emergence of human diseases in Ecuador, a small country in South America that lacks information on most of these pathogens. Methods and principal findings: A systematic review was carried out using PRISMA guidelines from 1927 until 2019 about blood-borne pathogens present in NHPs of the Neotropical region (i.e., South America and Middle America). Results: A total of 127 publications were found in several databases. We found in 25 genera (132 species) of NHPs a total of 56 blood-borne pathogens in 197 records where Protozoa has the highest number of records in neotropical NHPs $(n=128)$ compared to bacteria $(n=12)$ and viruses $(n=57)$. Plasmodium brasilianum and Trypanosoma cruzi are the most recorded protozoa in NHP. The neotropical primate genus with the highest number of blood-borne pathogens recorded is Alouatta sp. $(n=32)$. The use of non-invasive samples for neotropical NHPs remains poor in a group where several species are endangered or threatened. A combination of serological and molecular techniques is common when detecting blood-borne pathogens. Socioecological and ecological risk factors facilitate the transmission of these parasites. Finally, a large number of countries remain unsurveyed, such as Ecuador, which can be of public health importance. Conclusions and significance: NHPs are potential reservoirs of a large number of blood-borne pathogens. In Ecuador, research activities should be focused on bacteria and viruses, where there is a gap of information for neotropical NHPs, in order to implement surveillance programs with regular and effective monitoring protocols adapted to NHPs.

Keywords: Ecuador; non-human primates; Alouatta; blood-borne pathogen; protozoa; Plasmodium; Trypanosoma; yellow fever

\section{Introduction}

Wild animals are the cause of almost $70 \%$ of all emerging diseases [1], and more than $60 \%$ of these diseases are zoonotic [2]. This is a public health concern and a conservation problem [3,4]. Non-human primates (NHPs) are infected not only by gastrointestinal parasites [5], but also by ectoparasites, hemoparasites, bacteria, viruses and some arthropods that affect the lungs. Until recently [6,7], just a few studies identified blood pathogens from fecal samples due to the presence of DNA (deoxyribonucleic acid) inhibitors in fecal samples. Thereafter, just a few studies have identified hemoparasites such as Plasmodium sp. [8,9] and Trypanosoma brucei [10] and viruses such as adenovirus [11] and astrovirus [12] 
from NHPs' fecal samples. Most NHP species are listed under a category of conservation $[13,14]$. Molecular identification in fecal samples of blood-borne pathogens will be of great advantage to monitor NHP populations that can be a potential zoonotic reservoir for humans.

Gastrointestinal parasites have been monitored in neotropical primates [5,15-21]; however, they are restricted to some countries such as Mexico [22-33] and Brazil [34-44]. Regarding the study of hemoparasites and arboviruses in neotropical primates, this one is restricted just to a few studies in Brazil [45-48], Venezuela [49,50] and French Guiana [49], and Ecuador has no data on them [51], even if most of those hemoparasites and arboviruses are present in Ecuador [52-56]. Finally, we wish to focus on hemoparasites and arboviruses because they are the cause of millions of infections and thousands of deaths per year in humans [56-59]. Understanding whether primates act as a wild reservoir for hemoparasites and viruses in the neotropical region will allow us to better understand the ecology of diseases [60] and the role of NHPs in the emergence of human diseases [61], as well as the way to implement control programs [62,63] for endemic [64] and incoming pathogens [65] and NHP conservation/management plans in Ecuador [66].

Some NHPs can become infected with hemoparasite species of protozoans. For example, wildlife harbors several species of Plasmodium [67-69], especially NHPs. However, in the neotropics, just recently, there is evidence of natural infection in humans with Plasmodium brasilianum in Venezuela [70] and Plasmodium simium in Brazil [45]. Therefore, in order to identify potential zoonotic reservoirs in wildlife, it is essential to monitor Plasmodium sp. in the Amazon region of Ecuador. Another example, Toxoplasma sp., has a worldwide distribution and affects a wide range of hosts from humans [71] and domestic animals [72] to wildlife [3,73], including marine mammals [74], freshwater mammals [75] and NHPs, Old World (OW) and New World (NW) monkeys [48,76-79]. In Ecuador, however, screening to detect Toxoplasma was only carried out in the islands of Galapagos. Indeed, some studies found Toxoplasma in birds [80,81], domestic animals [82], as well as in environmental waters. Leishmania sp. occurs in a wide range of hosts [83-88], including human [89] and non-human primates [48]. In NHPs, experimental [90] and natural infections [91] have been registered. However, studies in the neotropics are restrained to Brazil, and countries such as Ecuador are under-surveyed even though the parasite is widely distributed [92]. In Ecuador, despite surveillance and control campaigns, trypanosomiasis is still present [93]. However, there are just a few studies of trypanosomiasis in wildlife: bats [94,95], marsupials and rodents [96], and frogs [97], and unfortunately there are none on primates. In addition, in NW monkeys, it is very common to find several species of trypanosomes such as Trypanosoma (megatrypanum) minasense [98], and also zoonotic trypanosomes: Trypanosoma rangeli and T. cruzi [99].

Viral infections also pose a threat to NHPs' health. Four types of viruses may affect NHPs: enveloped DNA (deoxyribonucleic acid) viruses, non-enveloped DNA viruses, enveloped RNA (ribonucleic acid) viruses and non-enveloped RNA viruses [100]. Among the latter, arboviruses (arthropod-borne viruses) are a diverse range of viruses from eight families: Togaviridae (genus Alphavirus), Flaviviridae (genus Flavivirus), Peribunyaviridae (example: genus Orthobunyavirus), Nairoviridae (example: genus Orthonairovirus), Phenuiviridae (example: genus Phlebovirus), Reoviridae (genus Orbivirus), Rhabdoviridae (genus Vesiculovirus) and Orthomyxoviridae (genus Thogotovirus).

Arboviruses are a public health concern due to the threat to both humans and animals [101,102]. Arbovirus hosts can vary from a specific taxonomic group to several hosts. The range of vectors can also vary in the same way. For some arboviruses, the zoonotic origin is linked to primates because of their close genetic distance, while others are linked to other vertebrates or the vector itself [103]. In the neotropics, NHPs have been identified as hosts for the following diseases: yellow fever [104-106], Mayaro virus [49], Zika virus, Chikungunya virus [107], hepatitis A [108], Cacipacoré virus [109], St. Louis encephalitis virus (SLEV) and Oropouche virus (OROV) [49,110]. 


\section{Results}

\subsection{Current Situation of Non-Human Primates \\ Non-Human Primate Biodiversity}

Primates from all over the world are divided into two groups: Old World Monkeys (Catarrhinni) and New World Monkeys (Platyrrhini). Around the world, we reported 504 species, including 171 species in the Neotropical region (i.e., South America and Middle America). The Neotropical region is the zoogeographical region with the highest number of species, and Ecuador registers 21 species (Table 1). All groups are mainly arboreal and they play an important role in cultures [111], in religions [112], in human livelihoods [113], and in the threat of emerging diseases [105]. They are also a good indicator of the quality of the environment [114], and at this time the destruction of their habitats, hunting and the capture of live specimens for export and local use are the greatest threats to their conservation [115-119].

Table 1. Species of non-human primates from Ecuador.

\begin{tabular}{|c|c|c|c|c|c|c|}
\hline Family & Primate Species & Size $(\mathrm{cm})$ & Weight (g) & $\begin{array}{l}\text { Group Size } \\
\text { (\# of } \\
\text { Individuals) }\end{array}$ & $\begin{array}{l}\text { Social } \\
\text { System } 1\end{array}$ & Habitat $^{2}$ \\
\hline \multirow[b]{2}{*}{ Aotidae } & Aotus lemurinus & 50 & 1300 & Small (1 to 5) & M & \multirow{2}{*}{$\begin{array}{c}\text { TFF } \\
\text { TFF, FF, and } \\
\text { crops }\end{array}$} \\
\hline & Aotus vociferans & 50 & 698 & Small (2-5) & M & \\
\hline \multirow{6}{*}{ Atelidae } & Alouatta seniculus & $43-60$ & $3600-9000$ & $\begin{array}{l}\text { Small (3-7) } \\
\text { or Large (15) }\end{array}$ & $\begin{array}{l}\text { MM-MF or a } \\
\text { group of } \\
\text { bachelor males }\end{array}$ & $\mathrm{FF}$ \\
\hline & $\begin{array}{l}\text { Alouatta palliata } \\
\text { aequatorialis }\end{array}$ & $48-67$ & 3100-9800 & $\begin{array}{l}\text { Small and } \\
\text { Medium } \\
(2-12)\end{array}$ & MM-MF & $\begin{array}{l}\text { All types of } \\
\text { forests }\end{array}$ \\
\hline & \multirow{4}{*}{$\begin{array}{c}\text { Ateles belzebuth } \\
\text { Ateles fusciceps } \\
\text { fusciceps } \\
\text { Lagothrix } \\
\text { lagotricha } \\
\text { lagotricha } \\
\text { Lagothrix } \\
\text { lagotricha } \\
\text { poeppigii }\end{array}$} & $40-60$ & $6000-10,500$ & Large $(\approx 20)$ & MM-MF & TFF \\
\hline & & $39-58$ & 8800 & Large (20-30) & $\mathrm{MM}-\mathrm{MF}$ & TFF \\
\hline & & $40-58$ & $3600-10,000$ & Large (6-60) & $\begin{array}{l}\text { PG/MM- } \\
\mathrm{MF} / \mathrm{MM}\end{array}$ & TFF \\
\hline & & $40-58$ & $3600-10,000$ & Large (2-25) & $\begin{array}{l}\text { PG/MM- } \\
\mathrm{MF} / \mathrm{MM}\end{array}$ & TFF \\
\hline \multirow{6}{*}{ Cebidae } & Cebus albifrons & $81-84$ & 1900-3900 & $\begin{array}{l}\text { Medium } \\
(5-30)\end{array}$ & \multirow{6}{*}{ PG/MM-MF } & \multirow{6}{*}{$\begin{array}{l}\text { All types of } \\
\text { forests }\end{array}$} \\
\hline & Cebus aequatorialis & $35-46$ & $1200-3600$ & $\begin{array}{l}\text { Medium } \\
(5-20)\end{array}$ & & \\
\hline & $\begin{array}{c}\text { Sapajus } \\
\text { macrocephalus }\end{array}$ & $35-50$ & $1700-4500$ & $\begin{array}{l}\text { Medium } \\
(5-20)\end{array}$ & & \\
\hline & $\begin{array}{l}\text { Cebus capucinus } \\
\text { capucinus }\end{array}$ & $35-45$ & 2900-3900 & $\begin{array}{l}\text { Medium } \\
(2-42) \\
\text { Medium and }\end{array}$ & & \\
\hline & Cebus yuracus & $81-84$ & 2900-3900 & $\begin{array}{l}\text { Large (10 and } \\
\quad 35-54)\end{array}$ & & \\
\hline & $\begin{array}{c}\text { Saimiri } \\
\text { cassiquiarensis } \\
\text { macrodon }\end{array}$ & $25-32$ & 600-1400 & $\begin{array}{l}\text { Large }>10 \text { and } \\
\text { up to } 100\end{array}$ & & \\
\hline \multirow{4}{*}{ Callitrichidae } & Cebuella pygmaea & $12-15$ & $100-140$ & $\begin{array}{l}\text { Small and } \\
\text { Medium } \\
(2-9)\end{array}$ & $\mathrm{M} / \mathrm{PA}$ & TFF, FF \\
\hline & $\begin{array}{l}\text { Leontocebus } \\
\text { nigricollis graellsi }\end{array}$ & $15-28$ & $350-470$ & $\begin{array}{l}\text { Small and } \\
\text { Medium } \\
(2-30)\end{array}$ & \multirow{2}{*}{$\begin{array}{c}\text { M/MM-MF } \\
\text { All kinds of } \\
\text { social } \\
\text { structures }\end{array}$} & TFF and FF \\
\hline & $\begin{array}{l}\text { Leontocebus } \\
\text { lagonotus }\end{array}$ & $17-27$ & $330-430$ & $\begin{array}{l}\text { Medium } \\
(2-10)\end{array}$ & & $\begin{array}{l}\text { All kind of } \\
\text { forest }\end{array}$ \\
\hline & $\begin{array}{l}\text { Leontocebus } \\
\text { tripartitus }\end{array}$ & $21-24$ & $218-240$ & $\begin{array}{c}\text { Small and } \\
\text { Medium-sized } \\
(4-10)\end{array}$ & PG & TFF and FF \\
\hline
\end{tabular}


Table 1. Cont.

\begin{tabular}{|c|c|c|c|c|c|c|}
\hline Family & Primate Species & Size $(\mathrm{cm})$ & Weight (g) & $\begin{array}{c}\text { Group Size } \\
\text { (\# of } \\
\text { Individuals) }\end{array}$ & $\begin{array}{l}\text { Social } \\
\text { System }\end{array}$ & Habitat $^{2}$ \\
\hline \multirow{5}{*}{ Pithecidae } & $\begin{array}{l}\text { Plecturocebus } \\
\text { discolor }\end{array}$ & $28-36$ & 900-1400 & $\begin{array}{c}\text { Small } \\
(2-5)\end{array}$ & \multirow{5}{*}{ M } & $\begin{array}{c}\text { FF-lianas } \\
\text { forest-forest } \\
\text { gaps }\end{array}$ \\
\hline & Cheracebus lucifer & $30-38$ & $800-1500$ & Small (2-5) & & TFF \\
\hline & $\begin{array}{c}\text { Pithecia } \\
\text { aequatorialis }\end{array}$ & $39-44$ & $2000-2500$ & Small (1-4) & & TFF \\
\hline & Pithecia milleri & $37-48$ & $2100-2600$ & Small (2-6) & & TFF and FF \\
\hline & Pithecia napensis & $37-48$ & $2100-2600$ & $\begin{array}{l}\text { Small and } \\
\text { Medium } \\
(4-8)\end{array}$ & & TFF \\
\hline
\end{tabular}

${ }^{1}$ Social system: $\mathrm{M}=$ Monogamous: A mating system in which only one male copulates with only one female; MM-MF = MultimaleMultifemale groups: A social group consisting of multiple adult males and multiple adult females; MM = Multi-males: Strong social relationships among males, often deriving from close kinship among those males as a result of male philopatry; PA = Polyandry: A mating system in which one female copulates with multiple males; PG = Polygynandry: A mating system in which members of both sexes copulate with multiple members of the opposite sex [120]; ${ }^{2}$ Habitat: TFF-Terra firme forest: forest with soils composed of clay or loam [121]; FF-Flooded forests: Forests characterized by trees waterlogged or submerged during a large part of the year [122]. Data on NHPs were obtained from the following references: $[123,124]$.

\subsection{Terminology \\ 2.2.1. Key Concepts}

Blood pathogens can infect NHPs. However, a lot of terms have been identified across studies. This is why we propose the following concepts based on international guidelines. A disease is considered to be an abnormal condition in one part of the body or in the entire animal with clinical signs [125]. An infectious disease is caused by an agent that infects a host and can be transmitted to other hosts [126]. Blood-borne pathogens are viruses, bacteria and parasites found in the blood that can cause a disease.

\subsubsection{Non-Invasive Samples and Detection Methods}

The source of DNA in NHPs can be hairs [127,128], feces [129,130], buccal cells from swabs [131-133] or food wadges [134], urine [135] and blood [98,136]. Non-invasive genetic sampling was defined by Taberlet, et al. [137] as "the source of the DNA left behind by the animal and that can be collected without having to catch or disturb the animal". Noninvasive samples have been used in several studies of a wide range of vertebrates, such as birds [138-140], marine mammals [141-143], wolves [144,145], amphibians [146,147], reptiles [148], fish [149,150] and non-human primates. Non-invasive samples are known to have low quality and low quantity of DNA [151-153]. Samples such as pure blood have better results, but their collection is considered to be invasive. There are even cases where wild animals have died when trapped or manipulated for sampling. Therefore, the use of non-invasive samples can minimize disturbance to animals when collected correctly. However, sometimes non-invasive samples can disturb the ecology of animals. For example, in animals where their feces is used to mark their territory [154], collecting the whole feces can disturb the territory of the animal. In conservation biology, the use of noninvasive samples is of the utmost importance when it comes to threatened or endangered species such as gorillas [155], and in some cases is legally mandated.

Bacteria $(n=3)$, protozoa $(n=29)$ and viruses $(n=24)$ have been reported to infect the blood of neotropical NHPs (Tables 2-4). Studies in NHPs use invasive samples to detect blood pathogens. Most detection methods on protozoa focus on a combination between microscopy, polymerase chain reaction (PCR) and serological methods such as enzyme-linked immunosorbent assay (ELISA) (Table 3). However, for viruses, they focus primarily on a hemagglutination test (Table 4), which is considered a test for the presence of a humoral immune response of NHPs to an infectious agent such as viruses. 
Table 2. Bacteria found in neotropical non-human primates.

\begin{tabular}{|c|c|c|c|c|c|}
\hline Bacteria & Host & Location & $\begin{array}{c}\text { Sampling } \\
\text { (Invasive } \\
\text { Non-invasive) }\end{array}$ & $\begin{array}{l}\text { Detection } \\
\text { Methods }{ }^{1}\end{array}$ & References \\
\hline Borrelia burgdorferi & Leontopithecus chrysomelas & Brazil & Invasive & Nested PCR & [156] \\
\hline Leptospira spp. & $\begin{array}{c}\text { Ateles fusciceps } \\
\text { Ateles geoffroyi vellerosus } \\
\text { Ateles geoffroyi } \\
\text { yucatanensis } \\
\text { Ateles hybridus } \\
\text { Callithrix jacchus } \\
\text { Callithrix pennicilata } \\
\text { Cebus sp. } \\
\text { Cebus albifrons } \\
\text { Cebus capucinus } \\
\text { Leontopithecus sp. } \\
\text { Leontopithecus chrysomelas } \\
\text { Saguinus leucopus } \\
\text { Saimiri sciureus } \\
\text { Sapajus apella }\end{array}$ & $\begin{array}{c} \\
\\
\text { Brazil } \\
\text { Colombia } \\
\text { French Guiana } \\
\text { Mexico }\end{array}$ & Invasive & $\begin{array}{c}\text { PCR } \\
\text { MAT } \\
\text { Serology }\end{array}$ & $\begin{array}{l}{[157]} \\
{[158]} \\
{[159]} \\
{[160]} \\
{[161]} \\
{[162]} \\
{[163]} \\
{[164]} \\
{[165]}\end{array}$ \\
\hline Mycoplasma spp. & $\begin{array}{c}\text { Alouatta sp. } \\
\text { Alouatta caraya } \\
\text { Saimiri sciureus } \\
\text { Sapajus apella } \\
\text { Sapajus flavius } \\
\text { Sapajus nigritus } \\
\text { Saguinus midas niger }\end{array}$ & $\begin{array}{c}\text { Brazil } \\
\text { French Guiana }\end{array}$ & Invasive & $\begin{array}{l}\text { TEM } \\
\text { PCR }\end{array}$ & $\begin{array}{l}{[166]} \\
{[167]} \\
{[168]} \\
{[169]} \\
{[170]} \\
{[171]} \\
{[172]}\end{array}$ \\
\hline
\end{tabular}

${ }^{1}$ TEM = Transmission electron microscopy; MAT = Modified agglutination test.

Table 3. Protozoa found in neotropical non-human primates.

\begin{tabular}{|c|c|c|c|c|c|}
\hline Protozoa & Host & Location & $\begin{array}{c}\text { Sampling } \\
\text { (Invasive } \\
\text { Non-Invasive) }\end{array}$ & $\begin{array}{l}\text { Detection } \\
\text { Methods }\end{array}$ & References \\
\hline Babesia sp. & $\begin{array}{l}\text { Alouatta seniculus } \\
\text { Ateles paniscus } \\
\text { Callithrix sp. } \\
\text { Pithecia pithecia } \\
\text { Saimiri sciureus }\end{array}$ & French Guiana & Invasive & BS & $\begin{array}{c}{[173]} \\
{[68]}\end{array}$ \\
\hline $\begin{array}{l}\text { Leishmania sp. } \\
\text { Leishmania } \\
\text { (Viannia) }\end{array}$ & $\begin{array}{c}\text { Alouatta guariba } \\
\text { Atelidae (unknown } \\
\text { species) } \\
\text { Aoutus azarai azarai } \\
\text { Aotus nigriceps } \\
\text { Callicebus nigrifrons } \\
\text { Callithrix jacchus } \\
\text { Callithrix penicillata } \\
\text { Cebus macrocephalus } \\
\text { Lagothrix cana } \\
\text { Leontopithecus crysomelas } \\
\text { Pithecia sp. } \\
\text { Pithecia irrorata } \\
\text { Saguinus imperator } \\
\text { Saimiri ustus madeirae } \\
\text { Sapajus apella } \\
\text { Sapajus xanthosternos }\end{array}$ & $\begin{array}{c}\text { Argentina } \\
\text { Brazil }\end{array}$ & Invasive & $\begin{array}{c}\text { ELISA } \\
\text { PCR } \\
\text { IIF } \\
\text { DAT } \\
\text { PCR-RFLP }\end{array}$ & $\begin{array}{c}{[174]} \\
{[175]} \\
{[91]} \\
{[176]} \\
{[177]}\end{array}$ \\
\hline $\begin{array}{l}\text { Leishmania } \\
\text { amazonensis }\end{array}$ & Ateles paniscus & Brazil & Invasive & $\begin{array}{c}\text { DNA } \\
\text { PCR and RFLP }\end{array}$ & [178] \\
\hline
\end{tabular}


Table 3. Cont.

\begin{tabular}{|c|c|c|c|c|c|}
\hline Protozoa & Host & Location & $\begin{array}{c}\text { Sampling } \\
\text { (Invasive } \\
\text { Non-Invasive) }\end{array}$ & $\begin{array}{l}\text { Detection } \\
\text { Methods }\end{array}$ & References \\
\hline $\begin{array}{l}\text { Leishmania } \\
\text { braziliensis }\end{array}$ & Saguinus geoffroyi & Panama & Invasive & $\mathrm{NA}^{1}$ & [179] \\
\hline $\begin{array}{c}\text { Leishmania chagasi } \\
\text { Leishmania } \\
\text { infantum }\end{array}$ & $\begin{array}{l}\text { Callicebus nigrifrons } \\
\text { Callithrix jacchus }\end{array}$ & Brazil & Invasive & $\begin{array}{l}\text { PCR } \\
\text { IHC } \\
\text { DAT }\end{array}$ & $\begin{array}{c}{[91]} \\
{[180]}\end{array}$ \\
\hline $\begin{array}{l}\text { Leishmania } \\
\text { mexicana }\end{array}$ & $\begin{array}{c}\text { Alouatta palliata } \\
\text { Alouatta pigra }\end{array}$ & Mexico & Invasive & $\begin{array}{c}\text { ELISA } \\
\text { IIF } \\
\text { Western Blot }\end{array}$ & [181] \\
\hline $\begin{array}{c}\text { Leishmania } \\
\text { (Viannia) shawi }\end{array}$ & $\begin{array}{l}\text { Chiropotes satanus } \\
\text { Sapajus apella }\end{array}$ & Brazil & Invasive & $\begin{array}{l}\text { Monoclonal } \\
\text { antibodies }\end{array}$ & [85] \\
\hline Plasmodium sp. & Alouatta seniculus & Brazil & Invasive & $\begin{array}{c}\text { Conventional } \\
\text { microscopy } \\
\text { (GIEMSA) } \\
\text { PCR }\end{array}$ & [182] \\
\hline Plasmodium vivax & $\begin{array}{c}\text { Alouatta caraya } \\
\text { Alouatta guariba clamitans } \\
\text { Alouatta seniculus } \\
\text { macconnelli } \\
\text { Sapajus apella }\end{array}$ & $\begin{array}{c}\text { Brazil } \\
\text { French Guiana }\end{array}$ & Invasive & $\begin{array}{c}\text { Microscopy } \\
\text { IFA } \\
\text { ELISA } \\
\text { PCR } \\
\text { Real-time PCR }\end{array}$ & $\begin{array}{l}{[183]} \\
{[184]} \\
{[185]} \\
{[186]} \\
{[187]}\end{array}$ \\
\hline $\begin{array}{l}\text { Plasmodium } \\
\text { brasilianum }\end{array}$ & $\begin{array}{c}\text { Alouatta sp. } \\
\text { Alouatta seniculus } \\
\text { Alouatta seniculus straminea } \\
\text { Alouatta caraya } \\
\text { Alouatta guariba clamitans } \\
\text { Alouatta guariba guariba } \\
\text { Aotus nigriceps } \\
\text { Ateles sp. } \\
\text { Ateles belzebuth } \\
\text { Ateles chamek } \\
\text { Ateles paniscus } \\
\text { Aotus nigriceps } \\
\text { Brachytheles arachnoides } \\
\text { Cacajao calvus } \\
\text { Cacajao rubicundus } \\
\text { Callicebus bruneus } \\
\text { Callicebus dubuis } \\
\text { Callicebus moloch } \\
\text { Callicebus personatus } \\
\text { Callicebus torquatus } \\
\text { Callithrix geoffroyi } \\
\text { Cebus sp. } \\
\text { Chiropotes albinasus } \\
\text { Chiropotes chiropotes } \\
\text { Chiropotus sp. } \\
\text { Chiropotes satanas } \\
\text { Lagothrix cana cana } \\
\text { Lagothrix lagotricha } \\
\text { lagotricha } \\
\text { Lagothrix lagotricha } \\
\text { poeppigii } \\
\text { Leontopithecus chrysomelas } \\
\text { Leontopithecus rosalia } \\
\text { Mico humeralifer } \\
\text { Pithecia monachus }\end{array}$ & $\begin{array}{c}\text { French Guiana } \\
\text { Brazil } \\
\text { Venezuela }\end{array}$ & Invasive & $\begin{array}{c}\text { BS } \\
\text { Conventional } \\
\text { microscopy } \\
\text { (GIEMSA) } \\
\text { PCR } \\
\text { ELISA }\end{array}$ & $\begin{array}{c}{[188]} \\
{[68]} \\
{[189]} \\
{[182]} \\
{[190]} \\
{[191]} \\
{[192]}\end{array}$ \\
\hline
\end{tabular}


Table 3. Cont.

\begin{tabular}{|c|c|c|c|c|c|}
\hline Protozoa & Host & Location & $\begin{array}{c}\text { Sampling } \\
\text { (Invasive } \\
\text { Non-Invasive) }\end{array}$ & $\begin{array}{l}\text { Detection } \\
\text { Methods }\end{array}$ & References \\
\hline & $\begin{array}{c}\text { Pithecia irrorata } \\
\text { Pithecia pithecia } \\
\text { Saguinus martinsi martinsi } \\
\text { Saguinus martinsi } \\
\text { ochraceous } \\
\text { Saguinus midas niger } \\
\text { Saguinus midas } \\
\text { Saimiri sp. } \\
\text { Saimiri sciureus } \\
\text { Saimiri sciureus sciureus } \\
\text { Saimiri sciureus boliviensis } \\
\text { Saimiri ustus } \\
\text { Sapajus apella apella } \\
\text { Sapajus apella macrocephalus } \\
\text { Sapajus robustus } \\
\text { Sapajus xanthosternos }\end{array}$ & & & & \\
\hline Plasmodium simium & $\begin{array}{c}\text { Alouatta guariba clamitans } \\
\text { Callicebus nigrifrons } \\
\text { Cebus sp. } \\
\text { Sapajus robustus } \\
\text { Sapajus xanthosternos }\end{array}$ & Brazil & $\begin{array}{c}\text { Invasive } \\
\text { Non-Invasive }\end{array}$ & $\begin{array}{c}\text { BS } \\
\text { PCR } \\
\text { PCR from fecal } \\
\text { samples } \\
\text { Nested PCR }\end{array}$ & $\begin{array}{c}{[193]} \\
{[174]} \\
{[183]} \\
{[190]} \\
{[9]}\end{array}$ \\
\hline $\begin{array}{l}\text { Plasmodium } \\
\text { falciparum }\end{array}$ & $\begin{array}{c}\text { Alouatta caraya } \\
\text { Alouatta guariba } \\
\text { Alouatta puruensis } \\
\text { Alouatta seniculus } \\
\text { macconnelli } \\
\text { Ateles chamek } \\
\text { Callicebus bruneus } \\
\text { Lagothrix cana cana } \\
\text { Sapajus apella }\end{array}$ & $\begin{array}{c}\text { Brazil } \\
\text { French Guiana }\end{array}$ & Invasive & $\begin{array}{c}\text { ELISA } \\
\text { IFA } \\
\text { PCR }\end{array}$ & $\begin{array}{l}{[188]} \\
{[185]}\end{array}$ \\
\hline Toxoplasma sp. & Alouatta seniculus & & Invasive & DAT & [9] \\
\hline Toxoplasma gondii & $\begin{array}{c}\text { Alouatta sp. } \\
\text { Alouatta belzebul } \\
\text { Alouatta caraya } \\
\text { Alouatta seniculus } \\
\text { Alouatta seniculus straminea } \\
\text { Ateles sp. } \\
\text { Ateles geoffroyi } \\
\text { Ateles paniscus paniscus } \\
\text { Aotus sp. } \\
\text { Aotus nigriceps } \\
\text { Brachyteles arachnoides } \\
\text { Cebus spp. } \\
\text { Cebus albifrons } \\
\text { Cebus capucinus } \\
\text { Callithrix sp. } \\
\text { Callithrix penicillata } \\
\text { Chiropotes satanas } \\
\text { Erythrocebus sp. } \\
\text { Leontopithecus sp. } \\
\text { Leontopithecus chrysomelas } \\
\text { Leontopithecus chrysopygus } \\
\text { Leontopithecus rosalia } \\
\text { Leontopithecus rosalia rosalia }\end{array}$ & $\begin{array}{c}\text { Argentina } \\
\text { Brazil } \\
\text { Colombia } \\
\text { French Guiana } \\
\text { Mexico }\end{array}$ & $\begin{array}{l}\text { Invasive } \\
\text { Necropsy }\end{array}$ & $\begin{array}{c} \\
\\
\\
\text { DAT } \\
\text { IFAT } \\
\text { MAT } \\
\text { PCR } \\
\text { Latex } \\
\text { agglutination kit } \\
\text { Indirect } \\
\text { hemagglutination } \\
\text { kit } \\
\text { ELISA } \\
\text { IHC } \\
\text { PCR-RFLP } \\
\text { Histology }\end{array}$ & $\begin{array}{l}{[194]} \\
{[195]} \\
{[196]} \\
{[197]} \\
{[198]} \\
{[199]} \\
{[200]} \\
{[201]} \\
{[202]} \\
{[203]} \\
{[204]} \\
{[205]} \\
{[206]} \\
{[207]} \\
{[48]} \\
{[208]} \\
{[209]} \\
{[210]} \\
{[211]} \\
{[212]} \\
{[213]} \\
{[214]} \\
{[215]} \\
{[76]}\end{array}$ \\
\hline
\end{tabular}


Table 3. Cont.

\begin{tabular}{|c|c|c|c|c|c|}
\hline Protozoa & Host & Location & $\begin{array}{c}\text { Sampling } \\
\text { (Invasive } \\
\text { Non-Invasive) }\end{array}$ & $\begin{array}{l}\text { Detection } \\
\text { Methods }\end{array}$ & References \\
\hline & $\begin{array}{l}\text { Lagothrix lagotricha } \\
\text { Saguinus imperator } \\
\text { Saguinus labiatus } \\
\text { Saguinus oedipus } \\
\text { Saimiri sp. } \\
\text { Saimiri boliviensis } \\
\text { Saimiri sciureus } \\
\text { Saimiri sciureus sciureus } \\
\text { Sapajus spp. } \\
\text { Sapajus apella } \\
\text { Sapajus libidinosus } \\
\text { Sapajus flavius } \\
\text { Pithecia pithecia pithecia }\end{array}$ & & & & $\begin{array}{l}{[216]} \\
{[217]} \\
{[218]}\end{array}$ \\
\hline Trypanosoma sp. & $\begin{array}{l}\text { Alouatta seniculus } \\
\text { Ateles paniscus } \\
\text { Pithecia pithecia } \\
\text { Saguinus leucopus } \\
\text { Saimiri sciureus }\end{array}$ & $\begin{array}{c}\text { Colombia } \\
\text { French Guiana } \\
\text { Panama }\end{array}$ & Invasive & BS & $\begin{array}{c}{[68]} \\
{[219]} \\
{[220]}\end{array}$ \\
\hline Trypanosoma cruzi & $\begin{array}{c}\text { Alouatta palliata } \\
\text { Alouatta pigra } \\
\text { Alouatta caraya } \\
\text { Alouatta seniculus } \\
\text { Ateles belzebuth } \\
\text { Ateles geoffroyi } \\
\text { Ateles fusciceps } \\
\text { Aotus sp. } \\
\text { Aotus azarai } \\
\text { Aotus nigriceps } \\
\text { Cacajao calvus } \\
\text { Callicebus personatus } \\
\text { Callicebus nigrifrons } \\
\text { Callithrix geoffroyi } \\
\text { Callithrix jacchus } \\
\text { Callithrix penicillata } \\
\text { Cebuella pygmaea } \\
\text { Cebus albifrons } \\
\text { Cebus capucinus } \\
\text { Cheracebus torquatus } \\
\text { Chiropotes satanas } \\
\text { Leontopithecus chrysopygus } \\
\text { Leontopithecus chrysomelas } \\
\text { Leontopithecus rosalia } \\
\text { Leontocebus fuscicollis } \\
\text { Leontocebus fuscicollis } \\
\text { weddelli } \\
\text { Leontocebus nigricollis } \\
\text { Mico chrysoleucus } \\
\text { Mico argentatus } \\
\text { Mico emiliae } \\
\text { Pithecia irrorata } \\
\text { Plecturocebus brunneus } \\
\text { Saguinus niger } \\
\text { Saguinus geoffroyi } \\
\text { Saguinus bicolor bicolor } \\
\text { Saguinus imperator } \\
\text { imperator }\end{array}$ & $\begin{array}{c}\text { Argentina } \\
\text { Brazil } \\
\text { Mexico } \\
\text { French Guiana } \\
\text { Panama } \\
\text { Peru }\end{array}$ & Invasive & $\begin{array}{l}\text { ELISA } \\
\text { IIF } \\
\text { PCR } \\
\text { BS } \\
\text { IFA } \\
\text { HC } \\
\text { XD }\end{array}$ & $\begin{array}{l}{[181]} \\
{[221]} \\
{[203]} \\
{[222]} \\
{[223]} \\
{[179]} \\
{[224]} \\
{[225]} \\
{[226]} \\
{[227]} \\
{[228]} \\
{[229]} \\
{[230]} \\
{[231]}\end{array}$ \\
\hline
\end{tabular}


Table 3. Cont.

\begin{tabular}{|c|c|c|c|c|c|}
\hline Protozoa & Host & Location & $\begin{array}{c}\text { Sampling } \\
\text { (Invasive } \\
\text { Non-Invasive) }\end{array}$ & $\begin{array}{l}\text { Detection } \\
\text { Methods }\end{array}$ & References \\
\hline & $\begin{array}{l}\text { Saguinus labiatus } \\
\text { Saguinus leucopus } \\
\text { Saguinus midas } \\
\text { Saguinus mystax } \\
\text { Saguinus ustus } \\
\text { Saimiri boliviensis } \\
\text { Saimiri sciureus } \\
\text { Saimiri ustus } \\
\text { Sapajus libidinosus } \\
\text { Sapajus robustus } \\
\text { Sapajus xanthosternos }\end{array}$ & & & & \\
\hline Trypanosoma devei & $\begin{array}{c}\text { Cebuella pygmaea } \\
\text { Callimico goeldii } \\
\text { Leontocebus fuscicollis } \\
\text { weddelli } \\
\text { Leontocebus tamarin tamarin } \\
\text { Saguinus imperator } \\
\text { imperator }\end{array}$ & Brazil & Invasive & $\mathrm{HC}$ & $\begin{array}{l}{[231]} \\
{[232]} \\
{[233]}\end{array}$ \\
\hline Trypanosoma diasi & Sapajus apella apella & Brazil & Invasive & $\mathrm{HC}$ & [232] \\
\hline $\begin{array}{l}\text { Trypanosoma } \\
\text { forestali }\end{array}$ & $\begin{array}{l}\text { Alouatta guariba } \\
\text { Alouatta caraya }\end{array}$ & $\begin{array}{c}\text { Argentina } \\
\text { Brazil }\end{array}$ & $\mathrm{NA}^{1}$ & $\mathrm{NA}^{1}$ & [223] \\
\hline $\begin{array}{l}\text { Trypanosoma } \\
\text { hippicum }\end{array}$ & $\begin{array}{l}\text { Alouatta guariba } \\
\text { Alouatta seniculus }\end{array}$ & NA & $\mathrm{NA}^{1}$ & $\mathrm{NA}^{1}$ & [219] \\
\hline $\begin{array}{l}\text { Trypanosoma } \\
\text { lambrechti }\end{array}$ & $\begin{array}{l}\text { Alouatta seniculus } \\
\text { Cebus albifrons } \\
\text { Cheracebus torquatus } \\
\text { Chiropotes satanas } \\
\text { Pithecia pithecia } \\
\text { Sapajus apella }\end{array}$ & Brazil & $\mathrm{NA}^{1}$ & $\mathrm{NA}^{1}$ & $\begin{array}{l}{[219]} \\
{[179]} \\
{[223]}\end{array}$ \\
\hline $\begin{array}{l}\text { Trypanosoma } \\
\text { lesourdi }\end{array}$ & Ateles paniscus & French Guiana & $\mathrm{NA}^{1}$ & $\mathrm{NA}^{1}$ & [223] \\
\hline $\begin{array}{l}\text { Trypanosoma } \\
\text { mycetae }\end{array}$ & $\begin{array}{c}\text { Alouatta belzebul } \\
\text { Alouatta belzebul belzebul } \\
\text { Alouatta palliata } \\
\text { Alouatta caraya } \\
\text { Alouatta seniculus } \\
\text { Chiropotes satanas }\end{array}$ & $\begin{array}{c}\text { Brazil } \\
\text { Guatemala } \\
\text { Panama } \\
\text { French Guiana }\end{array}$ & Invasive & $\begin{array}{c}\text { XD } \\
\text { Direct observation } \\
\text { of blood }\end{array}$ & $\begin{array}{l}{[229]} \\
{[233]} \\
{[232]} \\
{[223]} \\
{[224]} \\
{[219]}\end{array}$ \\
\hline $\begin{array}{l}\text { Trypanosoma } \\
\text { minasense }\end{array}$ & $\begin{array}{c}\text { Alouatta belzebul } \\
\text { Alouatta caraya } \\
\text { Alouatta guariba } \\
\text { Alouatta seniculus } \\
\text { Aotus trivirgatus } \\
\text { Ateles fusciceps } \\
\text { Ateles geoffroyi griscescens } \\
\text { Callithrix jacchus } \\
\text { Callithrix penicillata } \\
\text { Cebus albifrons } \\
\text { Cebus capucinus } \\
\text { Leontocebus weddelli } \\
\text { Leontocebus fuscicollis } \\
\text { weddelli } \\
\text { Plecturocebus ornatus }\end{array}$ & $\begin{array}{l}\text { Argentina } \\
\text { Brazil } \\
\text { Colombia } \\
\text { French Guiana } \\
\text { Panama } \\
\text { Peru }\end{array}$ & Invasive & $\begin{array}{c}\text { PCR } \\
\text { Stained films of } \\
\text { peripheral blood }\end{array}$ & $\begin{array}{l}{[232]} \\
{[179]} \\
{[203]} \\
{[229]} \\
{[234]} \\
{[223]} \\
{[98]} \\
{[224]} \\
{[231]} \\
{[230]} \\
{[235]}\end{array}$ \\
\hline
\end{tabular}


Table 3. Cont.

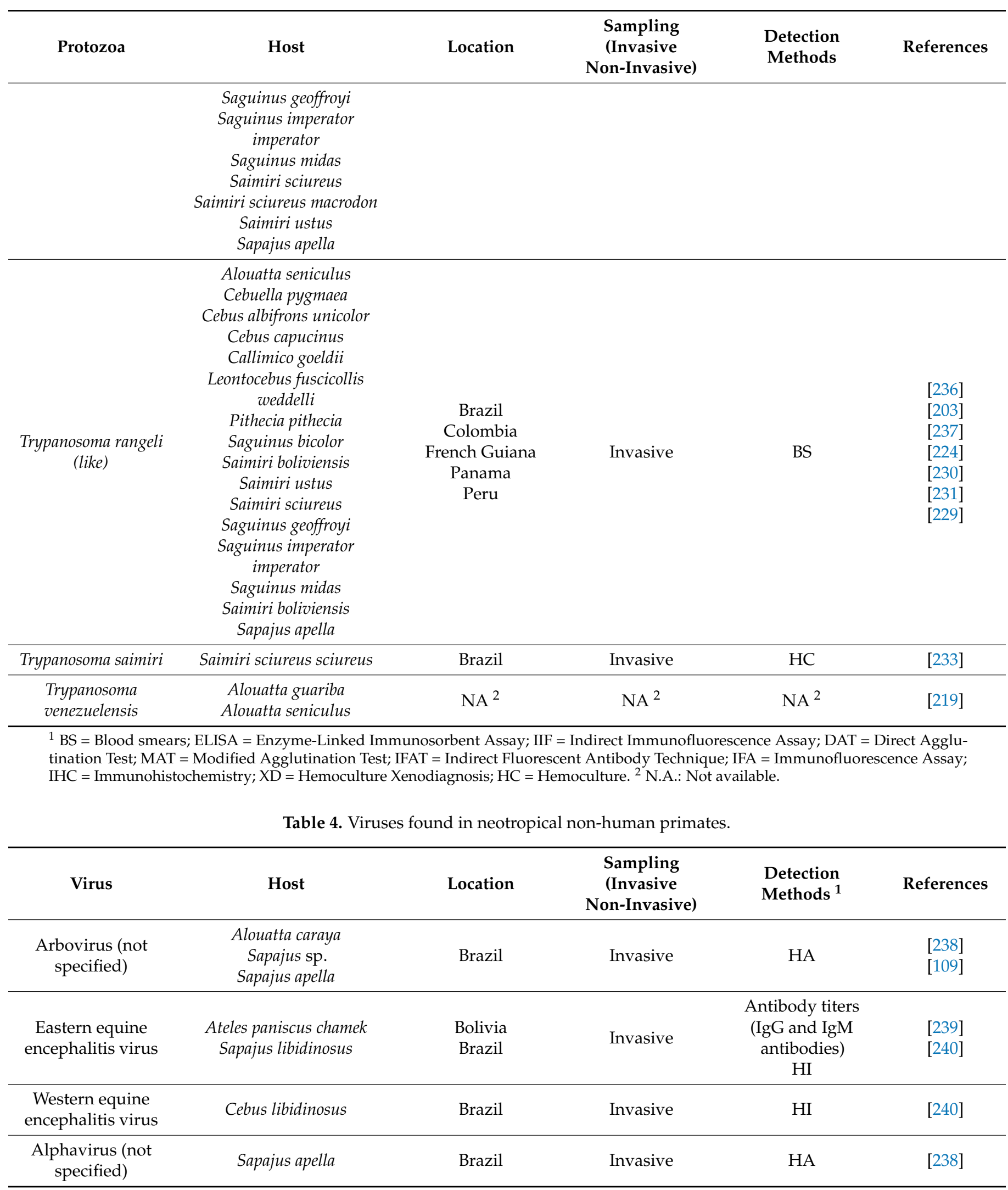


Table 4. Cont.

\begin{tabular}{|c|c|c|c|c|c|}
\hline Virus & Host & Location & $\begin{array}{c}\text { Sampling } \\
\text { (Invasive } \\
\text { Non-Invasive) }\end{array}$ & $\begin{array}{l}\text { Detection } \\
\text { Methods }\end{array}$ & References \\
\hline Mayaro virus & $\begin{array}{l}\text { Alouatta villosa } \\
\text { Alouatta seniculus } \\
\text { Callithrix argentata } \\
\text { Pithecia pithecia } \\
\text { Saguinus midas } \\
\text { Sapajus apella } \\
\text { Sapajus libidinosus }\end{array}$ & $\begin{array}{c}\text { Brazil } \\
\text { Panama } \\
\text { French Guiana }\end{array}$ & Invasive & $\begin{array}{c}\text { HA } \\
\text { Serologic (PRN } \\
\text { antibodies) } \\
\text { HI }\end{array}$ & $\begin{array}{l}{[238]} \\
{[203]} \\
{[241]} \\
{[240]} \\
{[242]} \\
{[243]}\end{array}$ \\
\hline Una virus & Alouatta caraya & $\begin{array}{l}\text { Argentina } \\
\text { Paraguay }\end{array}$ & Invasive & NTAb survey & [244] \\
\hline $\begin{array}{l}\text { Venezuelan equine } \\
\text { encephalitis virus }\end{array}$ & Sapajus apella & Colombia & Invasive & NTAb survey & [245] \\
\hline Mucambo virus & Sapajus libidinosus & Brazil & Invasive & $\mathrm{HI}$ & [240] \\
\hline $\begin{array}{l}\text { Flavivirus (not } \\
\text { specified) }\end{array}$ & $\begin{array}{c}\text { Leontopithecus chrysomelas } \\
\text { Sapajus apella } \\
\text { Sapajus xanthosternos }\end{array}$ & Brazil & Invasive & $\begin{array}{l}\mathrm{HA} \\
\mathrm{HI}\end{array}$ & $\begin{array}{l}{[238]} \\
{[246]}\end{array}$ \\
\hline West Nile virus & Alouatta caraya & Argentina & Invasive & RT-nested PCR & [247] \\
\hline Yellow fever virus & $\begin{array}{c}\text { Alouatta sp. } \\
\text { Alouatta caraya } \\
\text { Alouatta clamitans } \\
\text { Alouatta guariba clamitans } \\
\text { Alouatta fusca } \\
\text { Alouatta macconnellii } \\
\text { Alouatta seniculus } \\
\text { Ateles paniscus chamek } \\
\text { Callicebus sp. } \\
\text { Callithrix sp. } \\
\text { Cebus sp. } \\
\text { Leontopithecus sp. } \\
\text { Leontopithecus chrysomelas } \\
\text { Pithecia pithecia } \\
\text { Saguinus midas } \\
\text { Sapajus sp. } \\
\text { Sapajus libidinosus }\end{array}$ & $\begin{array}{c}\text { Argentina } \\
\text { Bolivia } \\
\text { Brazil } \\
\text { Colombia } \\
\text { French Guiana } \\
\text { Panama } \\
\text { Trinidad } \\
\text { Venezuela }\end{array}$ & $\begin{array}{l}\text { Invasive } \\
\text { Necropsy }\end{array}$ & $\begin{array}{l}\text { Immunoperoxidase } \\
\text { staining method } \\
\text { HI } \\
\text { ELISA IgM / } \\
\text { inoculated in mice } \\
\text { (Isolation by } \\
\text { RT-PCR) } \\
\text { IHC } \\
\text { RT-qPCR } \\
\text { RT-PCR } \\
\text { Serologic (PRN } \\
\text { antibodies) } \\
\text { Antibody titers } \\
\text { (IgG and IgM } \\
\text { antibodies) } \\
\text { Isolation in cell } \\
\text { cultures (Aedes } \\
\text { albopictus C3/36), } \\
\text { followed by DFA, } \\
\text { RT-PCR generic for } \\
\text { Flavivirus, and } \\
\text { genome } \\
\text { sequencing } \\
\text { IFAT } \\
\text { IIF using } \\
\text { monoclonal } \\
\text { antibodies }\end{array}$ & $\begin{array}{l}{[248]} \\
{[249]} \\
{[250]} \\
{[251]} \\
{[246]} \\
{[252]} \\
{[203]} \\
{[105]} \\
{[239]} \\
{[240]} \\
{[253]} \\
{[254]} \\
{[255]} \\
{[256]} \\
{[257]} \\
{[258]} \\
{[242]} \\
{[259]} \\
{[260]}\end{array}$ \\
\hline Ilheus virus & $\begin{array}{c}\text { Alouatta caraya } \\
\text { Callithrix jacchus } \\
\text { Callithrix penicillata } \\
\text { Leontopithecus chrysomelas } \\
\text { Sapajus libidinosus }\end{array}$ & $\begin{array}{l}\text { Argentina } \\
\text { Brazil }\end{array}$ & Invasive & $\begin{array}{c}\mathrm{HI} \\
\text { NT } \\
\text { RT-nested PCR }\end{array}$ & $\begin{array}{l}{[261]} \\
{[246]} \\
{[240]} \\
{[247]} \\
{[262]}\end{array}$ \\
\hline
\end{tabular}


Table 4. Cont.

\begin{tabular}{|c|c|c|c|c|c|}
\hline Virus & Host & Location & $\begin{array}{c}\text { Sampling } \\
\text { (Invasive } \\
\text { Non-Invasive) }\end{array}$ & $\begin{array}{l}\text { Detection } \\
\text { Methods }\end{array}$ & References \\
\hline $\begin{array}{l}\text { Saint Louis } \\
\text { encephalitis virus }\end{array}$ & $\begin{array}{c}\text { Alouatta caraya } \\
\text { Alouatta seniculus } \\
\text { Ateles paniscus chamek } \\
\text { Leontopithecus chrysomelas } \\
\text { Pithecia pithecia } \\
\text { Saguinus midas } \\
\text { Sapajus nigritus } \\
\text { Sapajus cay } \\
\text { Sapajus libidinosus }\end{array}$ & $\begin{array}{c}\text { Brazil } \\
\text { Argentina } \\
\text { French Guiana }\end{array}$ & Invasive & $\begin{array}{c}\text { HI } \\
\text { NT } \\
\text { MNT } \\
\text { RT-nested PCR }\end{array}$ & $\begin{array}{l}{[261]} \\
{[246]} \\
{[240]} \\
{[239]} \\
{[203]} \\
{[247]} \\
{[263]}\end{array}$ \\
\hline Rocio virus & $\begin{array}{c}\text { Leontopithecus chrysomelas } \\
\text { Sapajus libidinosus } \\
\text { Sapajus xanthosternos }\end{array}$ & Brazil & Invasive & $\mathrm{HI}$ & $\begin{array}{l}{[246]} \\
{[240]}\end{array}$ \\
\hline Zika virus & $\begin{array}{c}\text { Callithrix sp. } \\
\text { Leontopithecus chrysomelas } \\
\text { Sapajus sp. }\end{array}$ & Brazil & Invasive & $\mathrm{HI}$ & $\begin{array}{l}{[246]} \\
{[264]}\end{array}$ \\
\hline Dengue virus & Alouatta caraya & Argentina & Invasive & RT-nested PCR & [247] \\
\hline Bussuquara virus & $\begin{array}{c}\text { Alouatta caraya } \\
\text { Leontopithecus chrysomelas } \\
\text { Leontopithecus chrysopigus } \\
\text { Saguinus bicolor }\end{array}$ & $\begin{array}{l}\text { Argentina } \\
\text { Brazil }\end{array}$ & Invasive & $\begin{array}{c}\text { RT-nested PCR } \\
\text { NT } \\
\text { HI }\end{array}$ & $\begin{array}{l}{[246]} \\
{[247]} \\
{[265]}\end{array}$ \\
\hline Cacicapore virus & Leontopithecus chrysomelas & Brazil & Invasive & $\mathrm{HI}$ & [246] \\
\hline Orthobunyavirus & $\begin{array}{c}\text { Leontopithecus chrysomelas } \\
\text { Sapajus apella }\end{array}$ & Brazil & Invasive & $\mathrm{HI}$ & $\begin{array}{l}{[246]} \\
{[266]}\end{array}$ \\
\hline $\begin{array}{l}\text { Oropouche } \\
\text { orthobunyavirus }\end{array}$ & $\begin{array}{l}\text { Alouatta caraya } \\
\text { Callithrix sp. } \\
\text { Sapajus apella } \\
\text { Sapajus libidinosus }\end{array}$ & Brazil & Invasive & $\begin{array}{c}\text { HA } \\
\text { HI } \\
\text { Neutralization } \\
\text { assays } \\
\text { CF confirmed by } \\
\text { RT-PCR }\end{array}$ & $\begin{array}{l}{[238]} \\
{[267]} \\
{[240]} \\
{[268]}\end{array}$ \\
\hline Apeu virus & $\begin{array}{l}\text { Alouatta caraya } \\
\text { Sapajus apella }\end{array}$ & Brazil & Invasive & PRN T70 & [269] \\
\hline $\begin{array}{c}\text { Tacaiuma } \\
\text { orthobunyavirus }\end{array}$ & Leontopithecus chrysomelas & Brazil & Invasive & $\begin{array}{c}\text { HI } \\
\text { Real time PCR }\end{array}$ & [246] \\
\hline Phlebovirus & Leontopithecus chrysomelas & Brazil & Invasive & $\mathrm{HI}$ & [246] \\
\hline $\begin{array}{c}\text { Icoaraci } \\
\text { phlebovirus }\end{array}$ & $\begin{array}{c}\text { Alouatta caraya } \\
\text { Leontopithecus chrysomelas }\end{array}$ & Brazil & Invasive & $\begin{array}{l}\mathrm{HI} \\
\mathrm{NT}\end{array}$ & {$[246,261]$} \\
\hline
\end{tabular}

${ }^{1} \mathrm{HA}=$ Hemagglutination test; $\mathrm{HI}$ = Hemagglutination inhibition test; NATb = Neutralizing antibody (NTAb) survey; BS = Blood smears; ELISA = Enzyme-Linked Immunosorbent Assay; IHC = Immunohistochemistry; PRN = Plaque-reduction neutralizing; DFA = Direct Immunofluorescence Assay; IFAT = Indirect Fluorescent Antibody Technique; IIF = Indirect Immunofluorescence Assay; NT = Neutralization test; $\mathrm{MNT}=$ Mouse neutralization test $\mathrm{CF}=$ Complement fixation test.

\subsection{Risk Factors Associated with the Transmission of Disease}

There are several risk factors that favor the transmission of diseases such as socioecological and ecological factors (Table 5) [270,271]. 
Table 5. Risk factors associated with the transmission of diseases in neotropical non-human primates.

\begin{tabular}{|c|c|c|}
\hline Risk Factors & Factors & Examples \\
\hline Socioecological factors & $\begin{array}{l}\text { Animal behavior and social organization } \\
\text { Sleeping site ecology } \\
\text { Migration }\end{array}$ & $\begin{array}{c}\text { Group size } \\
\text { Movement between groups } \\
\text { Sexual selection number of mating partners } \\
\text { Type of contact and contact rate } \\
\text { Host age } \\
\text { Habitat } \\
\text { Animal } \\
\text { Humans }\end{array}$ \\
\hline Ecological factors & $\begin{array}{l}\text { Host density } \\
\text { Climate change }\end{array}$ & $\begin{array}{c}\text { High vs. low } \\
\text { Habitat shifts } \\
\text { Host switching } \\
\text { Primate behavior } \\
\text { Agricultural practices } \\
\text { Land-use changes } \\
\text { Malnutrition } \\
\text { Pollution }\end{array}$ \\
\hline
\end{tabular}

\subsubsection{Socioecological Factors}

- Animal behavior and social organization

Non-human primates are social, and as social animals they are at risk of infectious or parasitic diseases [272]. Factors such as group size, movement between groups, and sexual selection (number of mating partners) are among the variables of host-parasite interactions in NHPs that are considered to be drivers of parasite transmission [273]. Regarding group size, this variable is a risk factor for some infectious and parasitic diseases. In Amazonian primates, a larger group size will attract more mosquitos, and a higher risk of malaria infection was observed [274,275]. However, this is not true for other vectors [276]. There are strategies such as fission where subgrouping can act as a dilution effect for vectors [277]. The type of contact such as grooming [278] and the contact rate might also influence parasite transmission [279]. For example, lice transferred to other lemurs across several seasons [280] may increase the risk of infection of parasitic diseases [281,282]. Host age may also have an influence on the prevalence of hemoparasites in non-human primates [283]. For Plasmodium, the innate immune system plays a role in protecting young non-human primates from it and the parasite can benefit from an immune system weakened by age [284]. In Springer, et al. [285], Plasmodium sp. were more likely to infect older individuals of Verreaux's sifakas (Propithecus verreauxi), whereas Babesia sp. infected the younger ones.

- Sleeping site ecology

Sleeping behavior has been described as a risk factor for parasite transmission. It has been suggested that Amazonian NHPs sleeping in microhabitats are less likely to be infected with malaria [275]. In Milne-Edwards' sportive lemur (Lepilemur edwardsi), they are at greater risk of infection of ectoparasites and thus hemoparasites as well because they sleep in tree holes [286]. On the contrary, chimps (Pan troglodytes schweinfurthii) build their sleeping sites in Cynometra alexandri trees, which are known for having insect-repellent properties [287], decreasing the risk of infection.

\section{- Migration}

The OIE has not declared the presence of the West Nile virus in South America; however, three horses have died in Argentina and they were diagnosed with the WNV close to a North American cluster [288]. It has been suggested that wild bird migration could spread the virus to South America [289-291]. This scenario is not only valid for animals [292], but for humans as well [293]. The origins of Plasmodium falciparum and Plasmodium vivax in Central and South America are related to the migration of enslaved Africans and Australasian people, respectively [294]. 


\subsubsection{Ecological Factors}

\section{- Host density}

Host density is another risk factor that can increase parasite transmission [295,296]. However, lower densities such as those from orangutans (Pongo pygmaeus) (around two individuals per $\mathrm{km}^{2}$ ) can harbor as many as two species of malaria [297].

- Climate change

Climate change influences the emergence of infectious and parasitic diseases in several types of environments [298,299]. Several studies have described potential scenarios with models of climate change to describe distribution patterns of hosts and their pathogens and/or the vector [300,301]. As for the impact of climate change on NHPs, some studies have described habitat shifts at the altitudinal gradient [302] or at the latitudinal gradient [303]. Nunn, et al. [304] published a study on the latitudinal gradient of parasite species richness, which can give us an idea of how this distribution can impact NHPs if these ones change their distribution. In the neotropics, according to the modeling of the IPCC [305], some forests will shift to savannah woodlands, where this process could influence the hostparasite interaction [306,307]. The density and diversity of pathogens might be different in these savannas than in the forest $[308,309]$. Climate change could lead to host switching in NHPs [310] and an increase in the distribution of vectors [311-315]. For example, in avian malarias, host specificity was found in regions with pronounced rainfall seasonality [316]. However, pathogens can also adapt to new temperatures [317]. Finally, climate change can indirectly influence the behavior of primates, which can influence how pathogens can spread across populations. For example, climate change has a direct influence on the phenology of plants (e.g., fruiting, flowering) [318], and as a consequence, groups of NHPs forage differently for food [319-321], whether they fission into subgroups or whether they increase their home range for more food [322]. The implications of these changes are reflected on the host and might change the host-parasite relationship. According to HobergandBrooks [323], the primary sources of emerging infectious diseases will be those that are going to be able to survive climate change.

\subsubsection{Human Activities}

Human activities such as agricultural practices [324] and land-use changes (e.g., deforestation) [325,326] can increase the risk of parasite transmission [327]. For example, in Malaysian Borneo, macaque hosts and mosquito vectors are having more contact with humans due to these human activities [325]. In South America, there are also NHPs that survive in human-disturbed environments; thus, they can maintain the sylvatic cycle close to humans [69].

\subsubsection{Others}

Malnutrition [328,329] due to poor habitats (e.g., fragmentation) [307] and toxic chemicals and pollution are other factors that also increase parasite transmission [328].

\subsection{Surveillance Networks}

\subsubsection{World Organization for Animal Health (OIE)}

The animal health situation is monitored in each country and each country is responsible to declare to the OIE (World Organization for Animal Health). However, there are no notifications on NHPs for the Neotropical region or elsewhere. However, there are publications of some diseases such as yellow fever present in non-human primates [330]. For other diseases present in the OIE portal, the Ebola virus disease, for example, is not listed; however, they recommend it to be voluntarily reported [331,332]. In addition, the OIE have a guideline and a training manual on wildlife disease surveillance $[333,334]$, which could be applied as guidelines in Ecuador and other neotropical countries. 


\subsubsection{International Organizations from the United Nations System and Wildlife Monitoring}

The World Health Organization (WHO) work in collaboration with the FAO (Food and Agriculture Organization of the United Nations) and OIE to deal with zoonotic diseases. However, they also work with local governments, academia as well as nongovernmental organizations (NGOs). The FAO has several programs such as Vmergem, PAATS and LinkTads that have as objectives to help and to develop technical capacities for local governments.

\subsubsection{Local Networks}

The Ministry of Environment in Ecuador does not have a program on wildlife disease monitoring but it has workshops on wildlife health [335]. The National Institute of Research on Public Health (INSPI) has a program on parasites and infectious diseases, and they make guidelines for zoonotic wildlife diseases and wildlife groups such as NHPs. As for NGOs and management plans, there are none working on specific wildlife disease surveillance in Ecuador. However, the IUCN (International Union for Conservation of Nature) have international guidelines for each taxonomic group and their diseases, which can be applied by specialists all over the world [336-338]. Brazil is the only neotropical country with a guideline and a manual on epizootics in NHPs $[339,340]$. It is no coincidence that it is the country with the highest number of studies on neotropical NHP diseases (Tables 2-4).

\section{Discussion}

Diseases in NHPs are of conservation and medical importance because they may threaten both NHP populations [105,252] and humans [341,342]. That is why monitoring and long-term surveillance in NHPs $[343,344]$ can enhance the knowledge of diseases and the risks associated with them. However, we should pay attention to the choice of methods to detect NHP diseases. For example, for neotropical NHPs, just one study used a non-invasive method to monitor protozoa [9] (Tables 1-3). Invasive techniques such as serological tests, blood smears, and tissues are used to detect arthropod-borne diseases and blood pathogen diseases [345]. Instead, you can use fecal [8,346,347], urine [348] or saliva $[349,350]$ samples to monitor viruses, bacteria and other blood pathogens and obtain as much information as the other techniques as long as you only need to have an idea of the prevalence and the presence of the disease. Once you have a general idea of the current situation, in order to characterize the disease, you can move forward to an invasive technique but with fewer samples.

It is important to use non-invasive samples in wildlife studies since there are studies that determined the diagnostic sensitivity of molecular tests for the study of blood-borne pathogens, and obtained data close to invasive samples [351]. For example, for Plasmodium falciparum, a study determined by PCR the limit of detection at 6.5 parasites $/ \mu \mathrm{L}$ in fecal samples from NHPs from the Brazilian Amazon [9]. In human blood samples, the limit of detection of Plasmodium falciparum ranges from 0.03 parasites $/ \mu \mathrm{L}$ to 9 parasites $/ \mathrm{ml}$ using methods such as qPCR [352] and RT-PCR [353]. The sensitivity of parasite DNA extraction for both stool and blood samples will depend on sample storage [354], DNA extraction methods [355] and parasite densities in the population and in individuals [356,357]. Studies aim to improve molecular techniques to increase the sensitivity of these techniques in the diagnosis of pathogens [352,353,358,359].

Socioecological and ecological risk factors are associated with the transmission of blood-borne pathogens in NHPs. Factors such as human activities and climate change are identified as factors in the emergence of infectious diseases [360]. However, vectors must be considered to evaluate the transmission of these pathogens. For example, vector density and longevity would also increase the transmission rate of these pathogens [361]. Studies have even identified the feeding preferences of vectors and their connection to disease transmission [362,363]. Another study found an effect between habitat fragmentation and the infection rate of vectors with Plasmodium sp. [364]. 
Methods of surveillance should be adapted to wildlife populations. In captive settings, monitoring is easier than in wild populations. Additionally, the risk of infection can change whether they are captive or wild. Captive settings are an environment under control most of the time (depending on the captive conditions in neotropical countries), while monitoring free-ranging populations can be difficult for several reasons (poaching or legal hunting for meat, illegal pet trade, among others). However, long-term studies on NHPs may help to mitigate the effect of hunting [365]. NHPs from captive settings are most of the time from unknown origin [366], which makes it more difficult to know the biohazard threat involved. Sometimes the quarantine period is not respected, and diagnostic tests are not performed (either because they do not have the budget or because they are not aware of them), increasing the risk of infections. In addition to these conditions, the contact rate with humans such as care takers and tourists can introduce human pathogens to those populations (reverse zoonoses) [367], increasing the chances that an NHP can be infected. It is not unusual to see on social media, even during a pandemic, rescue center personnel or tourists taking pictures of themselves with primates without adequate biosecurity measures. In the other direction, pathogens can be transmitted to humans through primate biting (contact with body fluids) or scratches [368]. Cases of monkey bites in Ecuador are not unusual; however, local health services do not follow strict protocols such as taking samples from the patient and the monkey for further analysis or applying prophylaxis treatments against NHP bacteria or rabies.

In order to reduce the risks associated with the diseases, local governments should implement control measures adapted to NHPs. There are high risk activities such as NHP translocations [369] (from one geographical region to another or from one captive setting to another), reintroductions [370], among others, that can be a health risk for local populations of NHPs and humans. The success of these high-risk activities depends not only on NHP health but also on NHP socioecology, the support from local communities and the presence of environmental education programs [371]. NHP local populations and translocated groups should be monitored constantly. The costs of these activities are really high and losing individuals would be a step backwards. If the risk is too high, maybe the budget associated with this activity should be implemented in other types of conservation programs that could help primate populations more than the same translocation or reintroduction.

\section{Materials and Methods}

This systematic review was carried out using PRISMA guidelines for reporting systematic reviews and meta-analyses [372,373] and to identify bibliographic research from 1927 until 2019 about blood parasites, hemoparasites and arboviruses present in neotropical nonhuman primates. In several databases, we used the following search string (keywords and Boolean operators) "blood and parasites and primates", "Hemoparasites and Primates", "Haemoparasites and Primates", "Arbovirus and Primates" or "Parasites and Primates". The databases that we used were Scopus, Google Scholar and Pubmed. We also included grey literature such as theses and abstract presentations (Figure 1). Once the results were obtained, we made a selection by eliminating studies according to the following criteria: (1) the parasite was not a hemoparasite, (2) the published studies were in a language that the authors do not understand, (3) the study was not from a neotropical non-human primate, and finally (4) duplicate studies. We included all articles that clearly indicated the name of the parasite and the species of the host. We also included studies in captive and wild habitats. 


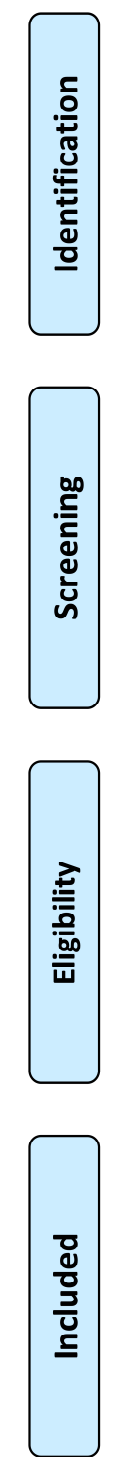
Records identified through database
searching $(n=296,200)$
Additional records identified through other sources $(n=48)$

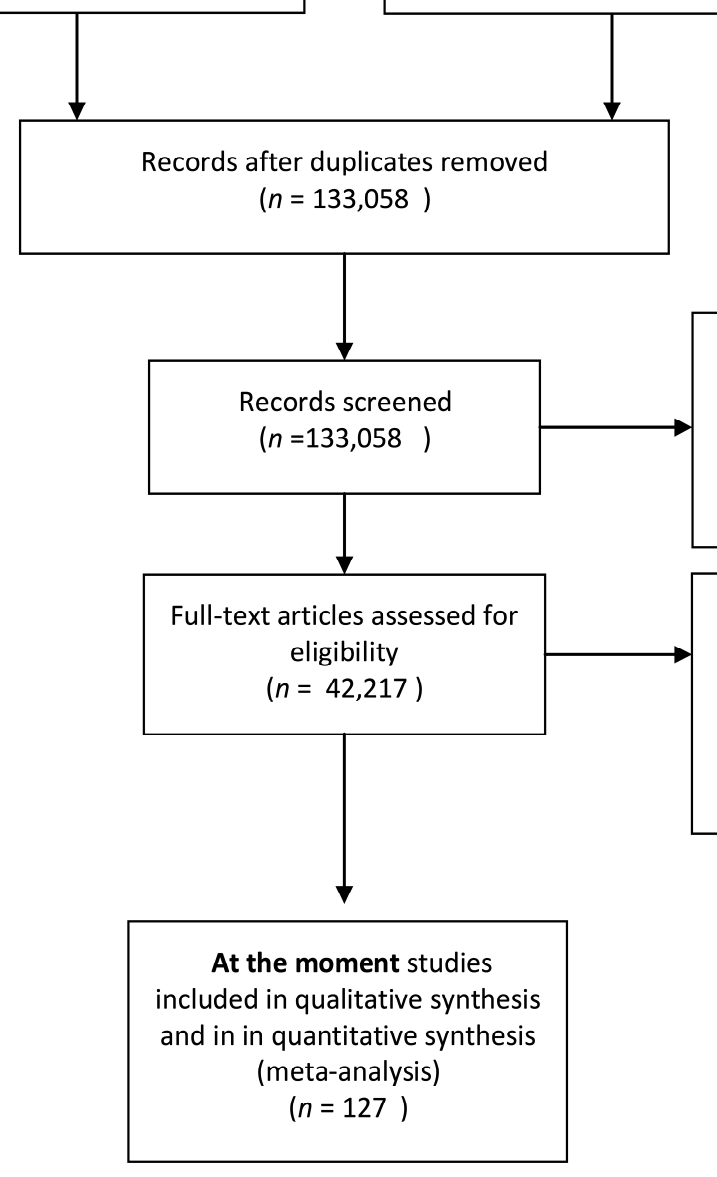

Records excluded by language (English, French, Spanish) and not related with primates and blood pathogens (by the title) $(n=90,841)$

Full-text articles excluded, with reasons (abstract it's not specific for our job, presence of confusing taxonomic information e.g. nonexistent species name) $(n=42,090)$

Figure 1. Flowchart (modified from PRISMA 2009) describing the literature search and study selection.

\section{Conclusions}

In this study, we found that NHPs are reservoirs for a large number of blood-borne pathogens. In addition, socioecological and ecological risk factors facilitate the transmission of these blood-borne pathogens either between NHPs or between NHPs and humans. The genus Alouatta is the one that records the highest number of blood-borne pathogens. This genus has the widest range of distribution from Mexico to Argentina. However, bacterial and viral pathogen groups have not been studied in depth in South America and especially in Ecuador, so these data will allow decision makers to decide where to focus their research efforts.

The Ministries of Health and Environment should prioritize the implementation of infection prevention and control measures in countries with a high risk of disease transmission. The Ministry of Environment should have a protocol to protect workers who are exposed to zoonotic diseases, for example, park rangers and zoo care takers, but also ecotourism. Ecotourism is considered a vulnerable group but also a group that exposes NHPs to infections [374,375]. A guideline should establish measures to prevent the introduction and spread of infection among NHP and human populations [376]. Some measures include reducing the frequency and duration of field visits as well as the number of visitors. Another biosecurity measure is to increase the viewing distance to NHPs [125,377]. Additionally, we should consider surveillance in national programs [378] as a tool for public 
health [333] and NHP conservation [3,338,379,380]. Finally, there are a large number of diseases that are under-surveyed. A large number of studies support surveillance programs as they improve the early detection of diseases [381-384]. These surveillance programs must have regular and effective monitoring protocols adapted to non-human primates. In order to implement these control programs, Ministries of Environment, Universities, and Health and wildlife researchers must collaborate with each other to determine monitoring strategies and to identify priority diseases for the country.

Author Contributions: Conceptualization, G.C.-B. and C.S.; methodology, G.C.-B.; validation, C.S., S.M.-S., G.C.-B.; formal analysis, G.C.-B., S.M.-S.; investigation, G.C.-B., C.S.; resources, G.C.-B., S.M.-S.; data curation, G.C.-B., S.M.-S.; writing-original draft preparation, G.C.-B.; writing-review and editing, C.S., S.M.-S.; visualization, G.C.-B., S.M.-S.; supervision, C.S.; project administration, G.C.-B.; funding acquisition, UCE-ULiège. All authors have read and agreed to the published version of the manuscript.

Funding: This work was funded the Academy of Research and Higher Education (ARES) through an institutional support program entitled "Hemoparasites and arboviruses in non-human primates of the Ecuadorian Amazon using non-invasive techniques", which involved the Universidad Central del Ecuador and the University of Liège in Belgium.

Institutional Review Board Statement: This study was approved by the Ministerio del Ambiente Ecuador under the permit number MAE-DNB-CM-2015-0028-M-002.

Informed Consent Statement: Not applicable.

Data Availability Statement: The data that support the findings of this study are available from the corresponding author upon reasonable request.

Acknowledgments: We would like to thank Ministerio del Ambiente for its support.

Conflicts of Interest: The authors declare no conflict of interest. The funders had no role in the design of the study; in the collection, analyses, or interpretation of data; in the writing of the manuscript, or in the decision to publish the results.

\section{References}

1. Kuiken, T.; Leighton, F.A.; Fouchier, R.A.; LeDuc, J.W.; Peiris, J.S.; Schudel, A.; Stöhr, K.; Osterhaus, A.D.M.E. Public health: Pathogen surveillance in animals. Science 2005, 309, 1680-1681. [CrossRef]

2. Jones, K.E.; Patel, N.G.; Levy, M.A.; Storeygard, A.; Balk, D.; Gittleman, J.L. Global trends in emerging infectious diseases. Nature 2008. [CrossRef]

3. Daszak, P.; Cunningham, A.A.; Hyatt, A.D. Emerging Infectious Diseases of Wildlife-Threats to Biodiversity and Human Health Science 2000, 287, 443-449. [CrossRef]

4. Gillespie, T.R.; Nunn, C.L.; Leendertz, F.H. Integrative Approaches to the Study of Primate Infectious Disease: Implications for Biodiversity Conservation and Global Health. Yrbk. Phys. Anth. 2008, 51, 53-69. [CrossRef] [PubMed]

5. Martin-Solano, S.; Carrillo-Bilbao, G.A.; Ramirez, W.; Celi-Erazo, M.; Huynen, M.-C.; Levecke, B.; Benitez, W.; Losson, B. Gastrointestinal parasites in captive and free-ranging Cebus albifrons in the Western Amazon, Ecuador. Int. J. Parasitol. Parasites Wildl. 2017, 6, 209-218. [CrossRef]

6. Liu, W.; Li, Y.; Learn, G.H.; Rudicell, R.S.; Robertson, J.D.; Keele, B.F.; Ndjango, J.-B.N.; Sanz, C.M.; Morgan, D.B.; Locatelli, S.; et al. Origin of the human malaria parasite Plasmodium falciparum in gorillas. Nature 2010, 467, 420-425. [CrossRef] [PubMed]

7. Victoria, J.G.; Kapoor, A.; Li, L.; Blinkova, O.; Slikas, B.; Wang, C.; Naeem, A.; Zaidi, S.; Delwart, E. Metagenomic Analyses of Viruses in Stool Samples from Children with Acute Flaccid Paralysis. J. Virol. 2009, 83, 4642-4651. [CrossRef]

8. Siregar, J.E.; Faust, C.L.; Murdiyarso, L.S.; Rosmanah, L.; Saepuloh, U.; Dobson, A.P.; Iskandriati, D. Non-invasive surveillance for Plasmodium in reservoir macaque species. Malar. J. 2015, 14, 404. [CrossRef]

9. de Assis, G.M.P.; de Alvarenga, D.A.M.; Costa, D.C.; de Souza, J.C.; Hirano, Z.M.B.; Kano, F.S.; de Sousa, T.N.; de Brito, C.F.A. Detection of Plasmodium in faeces of the New World primate Alouatta Clamitans. Mem. Inst. Oswaldo. Cruz 2016, 111, 570-576. [CrossRef] [PubMed]

10. Jirků, M.; Votýpka, J.; Petrželková, K.J.; Jirků-Pomajbíková, K.; Kriegová, E.; Vodička, R.; Lankester, F.; Leendertz, S.A.J.; Wittig, R.M.; Boesch, C.; et al. Wild chimpanzees are infected by Trypanosoma Brucei. Int. J. Parasitol. Parasites Wildl 2015, 4, $277-282$. [CrossRef]

11. Sukmak, M.; Wajjwalku, W.; Ostner, J.; Schülke, O. A first report of non-invasive adenovirus detection in wild Assamese macaques in Thailand. Primates 2017, 58, 307-313. [CrossRef] [PubMed] 
12. Wang, X.; Wang, J.; Zhou, C.; Yang, S.; Shen, Q.; Zhang, W.; Qi, D. Viral metagenomics of fecal samples from non-human primates revealed human astrovirus in a chimpanzee, China. Gut. Pathog. 2016, 8, 53. [CrossRef]

13. Schwitzer, C.; Mittermeier, R.A.; Rylands, A.B.; Chiozza, F.; Williamson, E.A.; Byler, D.; Wich, S.; Humle, T.; Johnson, C.; Mynott, H.; et al. (Eds.) Primates in Peril: The World's 25 Most Endangered Primates 2018-2020; IUCN SSC Primate Specialist Group, International Primatological Society, Global Wildlife Conservation, and Bristol Zoological Society: Washington, DC, USA, 2019 ; p. 130.

14. IUCN. The IUCN Red List of Threatened Species; IUCN: Grand, Switzerland, 2020.

15. Helenbrook, W.D.; Wade, S.E.; Shields, W.M.; Stehman, S.V.; Whipps, C.M. Gastrointestinal Parasites of Ecuadorian Mantled Howler Monkeys (Alouatta palliata aequatorialis) Based on Fecal Analysis. J. Parasitol. 2015, 101, 341-350. [CrossRef] [PubMed]

16. Kowalewski, M.M. Efectos de factores antropogénicos y demográficos sobre patrones de parasitismo gastrointestinal en monos aulladores negros y dorados. In Proceedings of the II Congreso Latinoamericano de Mastozoología, XXV Jornadas Argentinas de Mastozoología, Buenos Aires, Argentina, 29 September 2012.

17. Montesinos-López, G.M.; Pernía, M.; Pérez, A.; Aguirre, A.; Ceballos-Mago, N.; Rodríguez-Clark, K. Parásitos Gastrointestinales en Monos de Margarita Sapajus apella margaritae (Primates: Cebidae) en Estado Silvestre (Nueva Esparta, Venezuela). Hallazgos preliminares -resumen-. Mem. De La CIMA 2014, 10, 162-163.

18. Parr, N.; Fedigan, L.; Kutz, S. Predictors of Parasitism in Wild White-Faced Capuchins (Cebus capucinus). Int. J. Primatol. 2013, 34, 1137-1152. [CrossRef]

19. Perea-Rodriguez, J.P.; Milano, A.M.; Osherov, B.E.; Fernandez-Duque, E. Gastrointestinal parasites of Owl monkeys (Aotus azarai azarai) in the Argentinean Chaco. Neotrop. Primates 2010, 17, 7-11. [CrossRef]

20. Phillips, K.A.; Haas, M.E.; Grafton, B.W.; Yrivarren, M. Survey of the gastrointestinal parasites of the primate community at Tambopata National Reserve, Peru. J. Zool. 2004, 264, 149-151. [CrossRef]

21. Valdes Sanchez, V.V.; Saldaña Patiño, A.; Pineda Segundo, V.J.; Camacho Sandoval, J.A.; Charpentier Esquivel, C.V. Prevalence of Gastrointestinal Parasites among Captive Primates in Panama. J. Animal Vet. Adv. 2009, 8, 2644-2649.

22. Cristóbal-Azkarate, J.; Hervier, B.; Vegas-Carrillo, S.; Osorio-Sarabia, D.; Rodríguez-Luna, E.; Veà, J.J. Parasitic infections of three Mexican howler monkey groups (Alouatta palliata mexicana) living in forest fragments in Mexico. Primates 2010, 51, 231-239. [CrossRef] [PubMed]

23. Valdespino, C.; Rico-Hernández, G.; Mandujano, S. Gastrointestinal parasites of Howler monkeys (Alouatta palliata) inhabiting the fragmented landscape of the Santa Marta mountain range, Veracruz, Mexico. Am. J. Primatol. 2010, 72, 539-548. [CrossRef]

24. Aguilar Cucurachi, M.d.S.; Canales Espinosa, D.; Páez Rodríguez, M. Parásitos gastrointestinales en mono aullador (Alouatta palliata) en la región de Los Tuxtlas, Veracruz, México. A Primatol. No Bras. 2007, 10, 225-237.

25. Estrada, A. Parásitos Gastrointestinales en Poblaciones de Primates Silvestres en el Sureste de México. Available online: http:/ / www.primatesmx.com/fecalparesp.htm (accessed on 7 February 2007).

26. Gonzalez Hernández, M. Prevalencia de Helmintiasis Gastrointestinales en Monos Araña (Ateles geoffroyi) del Parque Zoológico Botánico Miguel Angel de Quevedo en Veracruz, México; Universidad Veracruzana: Veracruz, Mexico, 2004.

27. González-Hernández, M.; Rangel-Negrín, A.; Schoof, V.A.M.; Chapman, C.A.; Canales-Espinosa, D.; Dias, P.A.D. Transmission Patterns of Pinworms in Two Sympatric Congeneric Primate Species. Int. J. Primatol. 2014, 35, 445-462. [CrossRef]

28. Solórzano-García, B.; Pérez-Ponce de León, G. Helminth parasites of howler and spider monkeys in Mexico: Insights into molecular diagnostic methods and their importance for zoonotic diseases and host conservation. Int. J. Parasitol. Parasites Wildl. 2017, 6, 76-84. [CrossRef] [PubMed]

29. Stoner, K.E.; González-Di Pierro, A.M. Intestinal Parasitic Infections in Alouatta pigra in Tropical Rainforest in Lacandona, Chiapas, Mexico: Implications for Behavioral Ecology and Conservation. In New Perspectives in the Study of Mesoamerican Primates: Distribution, Ecology, Behavior, and Conservation; Estrada, A., Garber, P.A., Pavelka, M.S.M., Luecke, L., Eds.; Springer: New York, NY, USA, 2005.

30. Trejo-Macías, G.; Mosqueda-Cabrera, M.Á.; García-Prieto, L.; Estrada, A. Trypanoxyuris (Trypanoxyuris) minutus (Nematoda: Oxyuridae) en las dos especies de monos aulladores (Cebidae) de México. Rev. Mex Biodivers. 2011, 82, 293-299. [CrossRef]

31. Venturini, L.; Santa Cruz, A.C.; González, J.A.; Comolli, J.A.; Toccalino, P.A.; Zunino, G.E. Presencia de Giardia duodenalis (Sarcomastigophora, Hexamitidae) en mono aullador (Alouatta caraya) de vida silvestre. In Proceedings of the Comunicaciones Científicas y Tecnológicas; Universidad Nacional del Nordeste: Corrientes, Argentina, 2003.

32. Villanueva-García, C.; Gordillo-Chávez, E.J.; Baños-Ojeda, C.; Rendón-Franco, E.; Muñoz-García, C.I.; Carrero, J.C.; CórdobaAguilar, A.; Maravilla, P.; Galian, J.; Martínez-Hernández, F.; et al. New Entamoeba group in howler monkeys (Alouatta spp.) associated with parasites of reptiles. Parasitol. Res. 2017. [CrossRef]

33. Vitazkova, S.K.; Wade, S.E. Parasites of free-ranging black howler monkeys (Alouatta pigra) from Belize and Mexico. Am. J. Primatol. 2006, 68, 1089-1097. [CrossRef]

34. da Silva Barbosa, A.; Pissinatti, A.; Dib, L.V.; de Siqueira, M.P.; Cardozo, M.L.; Fonseca, A.B.M.; de Barros Oliveira, A.; da Silva, F.A.; Uchôa, C.M.A.; Bastos, O.M.P.; et al. Balantidium coli and other gastrointestinal parasites in captives non-human primates of the Rio de Janeiro, Brazil. J. Med. Primatol. 2015, 44, 18-26. [CrossRef]

35. David, É.B.; Patti, M.; Coradi, S.T.; Oliveira-Sequeira, T.C.G.; Ribolla, P.E.M.; Guimarães, S. Molecular typing of Giardia duodenalis isolates from nonhuman primates housed in a Brazilian zoo. Rev. Inst. Med. Trop. São Paulo 2014, 56, 49-54. [CrossRef] 
36. dos Santos Sales, I.; Ruiz-Miranda, C.R.; de Paula Santos, C. Helminths found in marmosets (Callithrix penicillata and Callithrix jacchus) introduced to the region of occurrence of golden lion tamarins (Leontopithecus rosalia). Vet. Parasitol. 2010, 171, 123-129. [CrossRef]

37. Fernandes, L.N.; Souza, P.P.; Araújo, R.S.; Razzolini, M.T.; Soares, R.M.; Sato, M.I. Detection of assemblages a and B of Giardia duodenalis in water and sewage from São Paulo state Brazil. J. Water Health 2011. [CrossRef] [PubMed]

38. Mati, V.L.T.; Junior, F.C.F.; Pinto, H.A.; de Melo, A.L. Strongyloides cebus (Nematoda: Strongyloididae) in Lagothrix cana (Primates: Atelidae) from the Brazilian Amazon: Aspects of Clinical Presentation, Anatomopathology, Treatment, and Parasitic Biology. J. Parasitol. 2013, 99, 1009-1018. [CrossRef] [PubMed]

39. Monteiro, R.V.; Jansen, A.M.; Pinto, R.M. Coprological helminth screening in Brazilian free ranging golden lion tamarins, Leontopithecus rosalia (L., 1766) (Primates, Callithrichidae). Braz. J. Biol. 2003, 63, 727-729. [CrossRef]

40. Pinto, H.A.; Ferreira, J.F.; Fau-Mati, V.L.T.; Mati Vl Fau-Melo, A.L.d.; Melo, A.L. Trypanoxyuris (Paraoxyuronema) lagothricis (Nematoda: Oxyuridae) in Lagothrix cana (Primates: Atelidae) from Brazil. Revista Brasileira de Parasitologia Veterinaria 2013, 22, 307-311. [CrossRef]

41. Souza de, P.; Magalhaes Cm Fau-Vieira, F.M.; Vieira Fm Fau-Souzalima, S.d.; Souzalima, S. Occurrence of Trypanoxyuris (Trypanoxyuris) minutus (Schneider, 1866) (Nematoda, Oxyuridae) in Alouatta guariba clamitans Cabrera, 1940 (Primates, Atelidae) in Minas Gerais, Brazil. Rev. Bras. Parasitol. Vet. 2010, 19, 124-126. [CrossRef]

42. Tenorio Mati, V.L.; Raso, P.; de Melo, A.L. Strongyloides stercoralis infection in marmosets: Replication of complicated and uncomplicated human disease and parasite biology. Parasit. Vectors 2014, 7, 579. [CrossRef]

43. Vicente, J.J.; Pinto, R.M.; Faria, Z. Spirura delicata sp. n. (Spiruridae, Spirurinae) from Leontocebus mystax (Callithrichidae) and a check list of other Nematodes of some brazilian primates. Mem Inst. Oswaldo Cruz 1992, 87, 305-308. [CrossRef]

44. Volotão, A.C.C.; Júnior, J.C.S.; Grassini, C.; Peralta, J.M.; Fernandes, O. Genotyping of Giardia duodenalis from Southern Brown Howler Monkeys (Alouatta clamitans) from Brazil. Vet. Parasitol. 2008, 158, 133-137. [CrossRef]

45. Brasil, P.; Zalis, M.G.; de Pina-Costa, A.; Siqueira, A.M.; Bianco Junior, C.; Silva, S.; Areas, A.L.L.; Pelajo-Machado, M.; de Alvarenga, D.A.M.; da Silva Santelli, A.C.F.; et al. Plasmodium simium causing human malaria: A zoonosis with outbreak potential in the Rio de Janeiro Brazilian Atlantic forest. bioRxiv 2017, 122127. [CrossRef]

46. Figueiredo, M.A.P.; Di Santi, S.M.; Manrique, W.G.; André, M.R.; Machado, R.Z. Identification of Plasmodium spp. in Neotropical primates of Maranhense Amazon in Northeast Brazil. PLoS ONE 2017, 12, e0182905. [CrossRef]

47. Guimaraes, L.; Bajay, M.; Wunderlich, G.; Bueno, M.; Rohe, F.; Catao-Dias, J.; Neves, A.; Malafronte, R.; Curado, I.; Kirchgatter, K. The genetic diversity of Plasmodium malariae and Plasmodium brasilianum from human, simian and mosquito hosts in Brazil. Acta Trop. 2012. [CrossRef] [PubMed]

48. Leite, T.N.; Maja Tde, A.; Ovando, T.M.; Cantadori, D.T.; Schimidt, L.R.; Guercio, A.C.; Cavalcanti, A.; Lopes, F.M.; Da Cunha, I.A.; Navarro, I.T. Occurrence of infection Leishmania spp. and Toxoplasma gondii in monkeys (Cebus apella) from Campo Grande, MS. Rev. Bras. De Parasitol. Vete. 2008, 17, 307-310.

49. Muñoz, M.; Navarro, J.C. Virus Mayaro: Un arbovirus reemergente en Venezuela y Latinoamérica. Biomédica 2012, 32, $286-302$. [CrossRef] [PubMed]

50. Navarro, J.C.; Giambalvo, D.; Hernandez, R.; Auguste, A.J.; Tesh, R.B.; Weaver, S.C.; Montanez, H.; Liria, J.; Lima, A.; Travassos da Rosa, J.F.; et al. Isolation of Madre de Dios Virus (Orthobunyavirus; Bunyaviridae), an Oropouche Virus Species Reassortant, from a Monkey in Venezuela. Am. J. Trop. Med. Hyg. 2016, 95, 328-338. [CrossRef] [PubMed]

51. Pappas, G.; Roussos, N.; Falagas, M.E. Toxoplasmosis snapshots: Global status of Toxoplasma gondii seroprevalence and implications for pregnancy and congenital toxoplasmosis. Int. J. Parasitol. 2009, 39, 1385-1394. [CrossRef] [PubMed]

52. Malaria, C.D.C. Information and Prophylaxis, by Country [E]. U.S. Department of Health \& Human Services.; 2018. Available online: https://www.cdc.gov/malaria/travelers/country_table/e.html:Atlanta (accessed on 17 January 2021).

53. Browne, A.J.; Guerra, C.A.; Alves, R.V.; da Costa, V.M.; Wilson, A.L.; Pigott, D.M.; Hay, S.I.; Lindsay, S.W.; Golding, N.; Moyes, C.L. The contemporary distribution of Trypanosoma cruzi infection in humans, alternative hosts and vectors. Sci. Data 2017, 4, 170050. [CrossRef]

54. WHO. Essential Leishmaniasis Maps Visceral and Mucocutaneous Leishmaniasis. 2018. Available online: http://www.who.int/ leishmaniasis/leishmaniasis_maps/en/ (accessed on 17 January 2021).

55. Rückert, C.; Weger-Lucarelli, J.; Garcia-Luna, S.M.; Young, M.C.; Byas, A.D.; Murrieta, R.A.; Fauver, J.R.; Ebel, G.D. Impact of simultaneous exposure to arboviruses on infection and transmission by Aedes aegypti mosquitoes. Nat. Commun. 2017, 8, 15412. [CrossRef] [PubMed]

56. Anez, G.; Chancey, C.; Grinev, A.; Rios, M. Dengue virus and other arboviruses: A global view of risks. ISBT Sci. Series 2012, 7, 274-282. [CrossRef]

57. WHO. WHO. World Malaria Report 2013. Available online: http://www.who.int/malaria/publications/world_malaria_report_ 2013/report/en/ (accessed on 17 January 2021).

58. WHO. World Malaria Report 2015. Global Malaria Programme; World Health Organisation: Geneva, Switzerland, 2016.

59. Gubler, D.; Meltzer, M. Impact of dengue/dengue hemorrhagic fever on the developing world. Adv. Virus Res. 1999, 53, 35-70.

60. Hudson, P.; Rizzoli, A.; Grenfell, B.; Heesterbeek, H.; Dobson, A. Ecology of Wildlife Diseases; OUP/Centro Di Ecologia Alpina: Oxford, UK, 2002; p. 216.

61. Wolfe, N.D.; Dunavan, C.P.; Diamond, J. Origins of major human infectious diseases. Nature 2007. [CrossRef] 
62. Drosten, C. Ecology and Species Barriers in Emerging Viral Diseases -Proposal for a DFG Priority Program (SPP); University of Bonn: Zentrum, Germany, 2010.

63. Joseph, M.B.; Mihaljevic, J.R.; Arellano, A.L.; Kueneman, J.G.; Preston, D.L.; Cross, P.C.; Johnson, P.T.J. Taming wildlife disease: Bridging the gap between science and management. J. Appl. Ecol. 2013, 50, 702-712. [CrossRef]

64. da Silva-Nunes, M.; Moreno, M.; Conn, J.E.; Gamboa, D.; Abeles, S.; Vinetz, J.M.; Ferreira, M.U. Amazonian malaria: Asymptomatic human reservoirs, diagnostic challenges, environmentally driven changes in mosquito vector populations, and the mandate for sustainable control strategies. Acta Trop. 2012, 121, 281-291. [CrossRef]

65. Maljkovic Berry, I.; Rutvisuttinunt, W.; Sippy, R.; Beltran-Ayala, E.; Figueroa, K.; Ryan, S.; Srikanth, A.; Stewart-Ibarra, A.M.; Endy, T.; Jarman, R.G. The origins of dengue and chikungunya viruses in Ecuador following increased migration from Venezuela and Colombia. BMC Evol. Biol. 2020, 20,31. [CrossRef] [PubMed]

66. Tirira, D.; Torre, S.; Zapata-Ríos, G. Plan. de Acción para la Conservación de los Primates del Ecuador; Ministerio del Ambiente (MAE)/Grupo de Estudio de Primates del Ecuador (GEPE)/Asociación Ecuatoriana de Mastozoología (AEM): Quito, Ecuador, 2018.

67. Bensch, S.; Stjernman, M.; Hasselquist, D.; Ostman, O.; Hansson, B.; Westerdahl, H.; Pinheiro, R.T. Host specificity in avian blood parasites: A study of Plasmodium and Haemoproteus mitochondrial DNA amplified from birds. Proc. R Soc. B 2000. [CrossRef]

68. de Thoisy, B.; Michel, J.-C.; Vogel, I.; Vié, J.-C. A survey of hemoparasite infections in free-ranging mammals and reptiles in french Guiana. J. Parasitol. 2000, 86, 1035-1040. [CrossRef]

69. Erkenswick, G.A.; Watsa, M.; Pacheco, M.A.; Escalante, A.A.; Parker, P.G. Chronic Plasmodium brasilianum infections in wild Peruvian tamarins. PLoS ONE 2017. [CrossRef]

70. Lalremruata, A.; Magris, M.; Vivas-Martínez, S.; Koehler, M.; Esen, M.; Kempaiah, P.; Jeyaraj, S.; Perkins, D.J.; Mordm Ã $\frac{1}{4}$ ller, B.; Metzger, W.G. Natural infection of Plasmodium brasilianum in humans: Man and monkey share quartan malaria parasites in the Venezuelan Amazon. EBioMedicine 2015, 2, 1186-1192. [CrossRef] [PubMed]

71. Iddawela, D.; Vithana, S.M.P.; Ratnayake, C. Seroprevalence of toxoplasmosis and risk factors of Toxoplasma gondii infection among pregnant women in Sri Lanka: A cross sectional study. BMC Public Health 2017, 17, 930. [CrossRef]

72. Gazzonis, A.L.; Marangi, M.; Villa, L.; Ragona, M.E.; Olivieri, E.; Zanzani, S.A.; Giangaspero, A.; Manfredi, M.T. Toxoplasma gondii infection and biosecurity levels in fattening pigs and sows: Serological and molecular epidemiology in the intensive pig industry (Lombardy, Northern Italy). Parasitol. Res. 2018. [CrossRef]

73. Wendte, J.M.; Gibson, A.K.; Grigg, M.E. Population genetics of Toxoplasma gondii: New perspectives from parasite genotypes in wildlife. Vet. Parasitol. 2011, 182, 96-111. [CrossRef]

74. Conrad, P.A.; Miller, M.A.; Kreuder, C.; James, E.R.; Mazet, J.; Dabritz, H.; Jessup, D.A.; Gulland, F.; Grigg, M.E. Transmission of Toxoplasma: Clues from the study of sea otters as sentinels of Toxoplasma gondii flow into the marine environment. Int. J. Parasitol. 2005, 35, 1155-1168. [CrossRef]

75. Chadwick, E.A.; Cable, J.; Chinchen, A.; Francis, J.; Guy, E.; Kean, E.F.; Paul, S.C.; Perkins, S.E.; Sherrard-Smith, E.; Wilkinson, C.; et al. Seroprevalence of Toxoplasma gondii in the Eurasian otter (Lutra lutra) in England and Wales. Parasit. Vectors 2013,6 , 75. [CrossRef]

76. Pena, H.F.J.; Marvulo, M.F.V.; Horta, M.C.; Silva, M.A.; Silva, J.C.R.; Siqueira, D.B.; Lima, P.A.C.P.; Vitaliano, S.N.; Gennari, S.M. Isolation and genetic characterisation of Toxoplasma gondii from a red-handed howler monkey (Alouatta belzebul), a jaguarundi (Puma yagouaroundi), and a black-eared opossum (Didelphis aurita) from Brazil. Vet. Parasitol. 2011, 175, 377-381. [CrossRef] [PubMed]

77. Poirotte, C.; Kappeler, P.M.; Ngoubangoye, B.; Bourgeois, S.; Moussodji, M.; Charpentier, M.J.E. Morbid attraction to leopard urine in Toxoplasma-infected chimpanzees. Curr. Biol. 2016, 26, R98-R99. [CrossRef]

78. Spencer, J.A.; Joiner, K.S.; Hilton, C.D.; Dubey, J.P.; Toivio-Kinnucan, M.; Minc, J.K.; Blagburn, B.L. Disseminated Toxoplasmosis in a Captive Ring-Tailed Lemur (Lemur catta). J. Parasitol. 2004, 90, 904-906. [CrossRef] [PubMed]

79. McConnell, E.E.; Basson, P.A.; Wolstenholme, B.; de Vos, V.; Malherbe, H.H. Toxoplasmosis in free-ranging chacma baboons (Papio ursinus) from The Kruger National Park. Trans. R. Soc. Trop. Med. Hyg. 1973, 67, 851-855. [CrossRef]

80. Deem, S.L.; Merkel, J.; Ballweber, L.; Vargas, F.H.; Cruz, M.B.; Parker, P.G. Exposure to Toxoplasma gondii in Galapagos Penguins (Spheniscus mendiculus) and Flightless Cormorants (Phalacrocorax harrisi) in the Galapagos Islands, Ecuador. J. Wildl. Dis. 2010, 46, 1005-1011. [CrossRef]

81. Deem, S.L.; Rivera-Parra, J.L.; Parker, P.G. Health evaluation of galapagos hawks (Buteo galapagoensis) on Santiago Island, Galapagos. J. Wildl. Dis. 2012, 48, 39-46. [CrossRef] [PubMed]

82. Verant, M.L.; d'Ozouville, N.; Parker, P.G.; Shapiro, K.; VanWormer, E.; Deem, S.L. Attempted Detection of Toxoplasma gondii Oocysts in Environmental Waters Using a Simple Approach to Evaluate the Potential for Waterborne Transmission in the Galápagos Islands, Ecuador. EcoHealth 2014, 11, 207-214. [CrossRef]

83. Gómez-Hernández, C.; Bento, E.C.; Rezende-Oliveira, K.; Nascentes, G.A.N.; Barbosa, C.G.; Batista, L.R.; Tiburcio, M.G.S.; Pedrosa, A.L.; Lages-Silva, E.; RamÍrez, J.D.; et al. Leishmania infection in bats from a non-endemic region of Leishmaniasis in Brazil. Parasitology 2017, 144, 1980-1986. [CrossRef]

84. Hashiguchi, Y.; Gomez, L.E.A.; Cáceres, A.G.; Velez, L.N.; Villegas, N.V.; Hashiguchi, K.; Mimori, T.; Uezato, H.; Kato, H. Andean cutaneous leishmaniasis (Andean-CL, uta) in Peru and Ecuador: The vector Lutzomyia sand flies and reservoir mammals. Acta Trop. 2018, 178, 264-275. [CrossRef] 
85. Lainson, R.; Braga, R.R.; De Souza, A.A.; Povoa, M.M.; Ishikawa, E.A.; Silveira, F.T. Leishmania (Viannia) shawi sp. n., a parasite of monkeys, sloths and procyonids in Amazonian Brazil. Ann. Parasitol. Hum. Comp. 1989, 64, 200-207. [CrossRef]

86. Otranto, D.; Testini, G.; Buonavoglia, C.; Parisi, A.; Brandonisio, O.; Circella, E.; Dantas-Torres, F.; Camarda, A. Experimental and field investigations on the role of birds as hosts of Leishmania infantum, with emphasis on the domestic chicken. Acta Trop. 2010, 113, 80-83. [CrossRef] [PubMed]

87. Quinnell, R.J.; Courtenay, O. Transmission, reservoir hosts and control of zoonotic visceral leishmaniasis. Parasitology 2009, 136, 1915-1934. [CrossRef] [PubMed]

88. Trüeb, I.; Portela, R.D.; Franke, C.R.; Carneiro, I.O.; Ribeiro, G.J.; Soares, R.P.; Barrouin-Melo, S.M. Trypanosoma cruzi and Leishmania sp. Infection in Wildlife from Urban Rainforest Fragments in Northeast Brazil. J. Wildl. Dis. 2017. [CrossRef]

89. Calvopina, M.; Aguirre, C.; Cevallos, W.; Castillo, A.; Abbasi, I.; Warburg, A. Coinfection of Leishmania guyanensis and Human Immunodeficiency Virus-Acquired Immune Deficiency Syndrome: Report of a Case of Disseminated Cutaneous Leishmaniasis in Ecuador. Am. J. Trop. Med. Hyg. 2017, 96, 1151-1154. [CrossRef]

90. Carneiro, L.A.; Silveira, F.T.; Campos, M.B.; Brígido, M.d.C.d.O.; Gomes, C.M.C.; Corbett, C.E.P.; Laurenti, M.D. Susceptibility of Cebus apella monkey (Primates: Cebidae) to experimental Leishmania (L.) infantum chagasi-infection. Rev. Inst. Med. Trop. Sao Paulo 2011, 53, 45-50. [CrossRef]

91. Malta, M.C.C.; Tinoco, H.P.; Xavier, M.N.; Vieira, A.L.S.; Costa, É.A.; Santos, R.L. Naturally acquired visceral leishmaniasis in non-human primates in Brazil. Vet. Parasitol. 2010, 169, 193-197. [CrossRef]

92. Hashiguchi, Y.; Velez, L.N.; Villegas, N.V.; Mimori, T.; Gomez, E.A.L.; Kato, H. Leishmaniases in Ecuador: Comprehensive review and current status. Acta Trop. 2017, 166, 299-315. [CrossRef] [PubMed]

93. Dumonteil, E.; Herrera, C.; Martini, L.; Grijalva, M.J.; Guevara, A.G.; Costales, J.A.; Aguilar, H.M.; Brenière, S.F.; Waleckx, E. Chagas Disease Has Not Been Controlled in Ecuador. PLoS ONE 2016, 11, e0158145. [CrossRef]

94. Cottontail, V.M.; Kalko, E.K.V.; Cottontail, I.; Wellinghausen, N.; Tschapka, M.; Perkins, S.L.; Pinto, C.M. High Local Diversity of Trypanosoma in a Common Bat Species, and Implications for the Biogeography and Taxonomy of the T. cruzi Clade. PLoS ONE 2014, 9, e108603. [CrossRef] [PubMed]

95. Pinto, C.M.; Ocaña-Mayorga, S.; Tapia, E.E.; Lobos, S.E.; Zurita, A.P.; Aguirre-Villacís, F.; MacDonald, A.; Villacís, A.G.; Lima, L.; Teixeira, M.M.G.; et al. Bats, Trypanosomes, and Triatomines in Ecuador: New Insights into the Diversity, Transmission, and Origins of Trypanosoma cruzi and Chagas Disease. PLoS ONE 2015, 10, e0139999. [CrossRef]

96. Ocaña-Mayorga, S.; Aguirre-Villacis, F.; Pinto, C.M.; Vallejo, G.A.; Grijalva, M.J. Prevalence, Genetic Characterization, and 18S Small Subunit Ribosomal RNA Diversity of Trypanosoma rangeli in Triatomine and Mammal Hosts in Endemic Areas for Chagas Disease in Ecuador. Vector Borne Zoonotic Dis. 2015, 15, 732-742. [CrossRef]

97. Bernal, X.E.; Pinto, C.M. Sexual differences in prevalence of a new species of trypanosome infecting túngara frogs. Int. J. Parasitol. Parasit. Wildl. 2016, 5, 40-47. [CrossRef] [PubMed]

98. Sato, H.; Leo, N.; Katakai, Y.; Takano, J.-i.; Akari, H.; Nakamura, S.-i.; Une, Y. Prevalence and molecular phylogenetic characterization of Trypanosoma (megatrypanum) minasense in the peripheral blood of small neotropical primates after a quarantine period. J. Parasitol. 2008, 94, 1128-1138. [CrossRef]

99. Aysanoa, E.; Mayor, P.; Mendoza, A.P.; Zariquiey, C.M.; Morales, E.A.; Pérez, J.G.; Bowler, M.; Ventocilla, J.A.; González, C.; Baldeviano, G.C.; et al. Molecular Epidemiology of Trypanosomatids and Trypanosoma cruzi in Primates from Peru. EcoHealth 2017, 14, 732-742. [CrossRef]

100. Wachtman, L.; Mansfield, K. Chapter 1-Viral Diseases of Nonhuman Primates. In Nonhuman Primates in Biomedical Research, 2nd ed.; Academic Press: Boston, MA, USA, 2012; pp. 1-104.

101. Jonduo, M.H.; Bande, G.; Horwood, P.F. Arboviruses of human health significance in Papua New Guinea. P N G Med. J. 2012, 55, 35-44.

102. Young, P.R.; Ng, L.F.P.; Hall, R.A.; Smith, D.W.; Johansen, C.A. 14-Arbovirus Infections. In Manson's Tropical Infectious Diseases, 23rd ed.; W.B. Saunders: London, UK, 2014; pp. 129-161.e123.

103. Hanley, K.A.; Weaver, S.C. Chapter 16-Arbovirus Evolution. In Origin and Evolution of Viruses, 2nd ed.; Parrish, C.R., Holland, J.J., Eds.; Academic Press: London, UK, 2008; pp. 351-391.

104. Moreno, E.S.; Agostini, I.; Holzmann, I.; Di Bitetti, M.S.; Oklander, L.I.; Kowalewski, M.M.; Beldomenico, P.M.; Goenaga, S.; Martínez, M.; Lestani, E.; et al. Yellow fever impact on brown howler monkeys (Alouatta guariba clamitans) in Argentina: A metamodelling approach based on population viability analysis and epidemiological dynamics. Mem. Inst. Oswaldo Cruz 2015, 110, 865-876. [CrossRef] [PubMed]

105. Holzmann, I.; Agostini, I.; Areta, J.I.; Ferreyra, H.; Beldomenico, P.; Di Bitetti, M.S. Impact of yellow fever outbreaks on two howler monkey species (Alouatta guariba clamitans and A. caraya) in Misiones, Argentina. Am. J. Primatol. 2010, 72, 475-480. [CrossRef]

106. Fernandes, N.C.C.d.A.; Cunha, M.S.; Guerra, J.M.; Réssio, R.A.; Cirqueira, C.d.S.; Iglezias, S.D.A.; de Carvalho, J.; Araujo, E.L.L.; Catão-Dias, J.L.; Díaz-Delgado, J. Outbreak of Yellow Fever among Nonhuman Primates, Espirito Santo, Brazil, 2017. Emerg. Infect. Dis. 2017, 23, 2038-2041. [CrossRef] [PubMed]

107. Moreira-Soto, A.; Carneiro, I.d.O.; Fischer, C.; Feldmann, M.; Kümmerer, B.M.; Silva, N.S.; Santos, U.G.; Souza, B.F.d.C.D.; Liborio, F.d.A.; Valença-Montenegro, M.M.; et al. Limited Evidence for Infection of Urban and Peri-urban Nonhuman Primates with Zika and Chikungunya Viruses in Brazil. mSphere 2018, 3, e00523-17. [CrossRef] 
108. Svoboda, W.K.; Soares, M.d.C.P.; Alves, M.M.; Rocha, T.C.; Gomes, E.C.; Menoncin, F.; Batista, P.M.; da Silva, L.R.; Headley, S.A.; Hilst, C.L.S.; et al. Serological detection of hepatitis a virus in free-ranging neotropical primates (Sapajus spp., Alouatta caraya) from the Paraná River Basin, BrazilL. Rev. Inst. Med. Trop. S Paulo. 2016, 58, 9. [CrossRef]

109. Batista, P.M.; Andreotti, R.; Almeida, P.S.; Marques, A.C.; Rodrigues, S.G.; Chiang, J.O.; Vasconcelos, P.F. Detection of arboviruses of public health interest in free-living New World primates (Sapajus spp.; Alouatta caraya) captured in Mato Grosso do Sul, Brazil. Rev. Soc. Bras. Med. Trop. 2013, 46, 684-690. [CrossRef] [PubMed]

110. Barreto Almeida, M.A.; da C. Cardoso, J.; dos Santos, E.; Martins Romano, A.P.; Chiang, J.O.; Carício Martins, L.; da Costa Vasconcelos, P.F.; Bicca-Marques, J.C. Immunity to Yellow Fever, Oropouche and Saint Louis viruses in a wild howler monkey. Neotrop. Primates 2016, 23, 19.

111. Rice, P.M.; South, K.E. Revisiting monkeys on pots: A contextual consideration of primate imagery on classic lowland maya pottery. Anc. Mesoam. 2015, 26, 275-294. [CrossRef]

112. Alves, R.R.N.; Souto, W.M.S.; Barboza, R.R.D. The Role of Nonhuman Primates in Religious and Folk Medicine Beliefs. In Ethnoprimatology: Primate Conservation in the 21st Century; Waller, M.T., Ed.; Springer International Publishing: Cham, Switzerland, 2016; pp. 117-135.

113. Hofner, A.N. Primate Conservation and Human Livelihoods. Int. Encycl. Primatol. 2017. [CrossRef]

114. Onderdonk, D.A.; Chapman, C.A. Coping with Forest Fragmentation: The Primates of Kibale National Park, Uganda. Int. J. Primatol. 2000, 21, 587-611. [CrossRef]

115. Emmons, L.H. (Ed.) Neotropical Rainforest Mammals: A Field Guide, 2nd ed.; The University of Chicago Press: Chicago, IL, USA, 1997; p. 396.

116. Estrada, A.; Garber, P.; Rylands, A.; Roos, C.; Fernandez-Duque, E.; Di Fiore, A.; Nekaris, K.A.; Nijman, V.; Heymann, E.; Lambert, J.; et al. Impending extinction crisis of the world's primates: Why primates matter. Sci. Adv. 2017, 3, e1600946. [CrossRef] [PubMed]

117. Chapman, C.A.; Onderdonk, D.A. Forests without primates: Primate/plant codependency. Am. J. Primatol. 1998, 45, 127-141. [CrossRef]

118. Mittermeier, R.A.; Cheney, D.L. Chapter 39: Conservation of primates and their habitats. In Primate Societies; Smuts, B.B., Cheney, D.L., Seyfarth, R.M., Wrangham, R.W., Struhsaker, T.T., Eds.; University of Chicago Press: Chicago, IL, USA, 1987; pp. 477-490.

119. Chapman, C.A.; Peres, C.A. Primate Conservation in the New Millennium: The Role of Scientists. Evol. Anthropol. 2001, 10, 16-33. [CrossRef]

120. Swedell, L. Primate Sociality and Social Systems. Nat. Educ. Knowl. 2012, 3, 84.

121. Tuomisto, H.; Ruokolainen, K.; Yli-Halla, M. Dispersal, environment, and floristic variation of western Amazonian forests. Science 2003, 299, 241-244. [CrossRef]

122. Parolin, P.; De Simone, O.; Haase, K.; Waldhoff, D.; Rottenberger, S.; Kuhn, U.; Kesselmeier, J.; Kleiss, B.; Schmidt, W.; Pledade, M.T.F.; et al. Central Amazonian floodplain forests: Tree adaptations in a pulsing system. Bot. Rev. 2004, 70, 357-380. [CrossRef]

123. Tirira, D.; de la Torre, S.; Zapata, G. Estado de Conservación de los Primates del Ecuador; Tirira, D., de la Torre, S., Zapata, G., Eds.; Editorial Murciélago Blanco: Quito, Ecuador, 2018.

124. Smuts, B.B.; Cheney, D.L.; Seyfarth, R.M.; Wrangham, R.W. Primate Societies; Smuts, B.B., Cheney, D.L., Seyfarth, R.M., Wrangham, R.W., Eds.; University of Chicago Press: Chicago, IL, USA, 1987; p. 585.

125. Gilardi, K.; Gillespie, T.R.; Leendertz, F.H.; Macfie, E.J.; Travis, D.A.; Whittier, C.A.; Williamson, E.A. Best Practice Guidelines for Health Monitoring and Disease Control. in Great Ape Populations. Occas. Papers IUCN Species Surviv. Comm.Gland 2015, 56. [CrossRef]

126. NIH. Understanding Emerging and Re-emerging Infectious Diseases. Biological Sciences Curriculum Study. NIH Curriculum Supplement Series Bethesda (MD): National Institutes of Health (US). 2007. Available online: https://www.ncbi.nlm.nih.gov/ books / NBK20370/ (accessed on 17 January 2021).

127. Tan, A.W.Y.; Dominy, N.J. Validation of a Noninvasive Hair Trapping Method for Extractive-Foraging Primates. Folia Primatol. 2018, 89, 415-422. [CrossRef]

128. Constable, J.L.; Ashley, M.V.; Goodall, J.; Pusey, A.E. Noninvasive paternity assignment in Gombe chimpanzees. Mol. Ecol. 2001, 10, 1279-1300. [CrossRef]

129. Chaves, P.B.; Paes, M.F.; Mendes, S.L.; Strier, K.B.; Louro, I.D.; Fagundes, V. Noninvasive genetic sampling of endangered muriqui (Primates, Atelidae): Efficiency of fecal DNA extraction. Genet. Mol. Biol. 2006, 29, 750-754. [CrossRef]

130. Arandjelovic, M.; Head, J.; Rabanal, L.I.; Schubert, G.; Mettke, E.; Boesch, C.; Robbins, M.M.; Vigilant, L. Non-Invasive Genetic Monitoring of Wild Central Chimpanzees. PLoS ONE 2011, 6, e14761. [CrossRef] [PubMed]

131. Toyoda, A.; Matsudaira, K.; Maruhashi, T.; Malaivijitnond, S.; Kawamoto, Y. Highly Versatile, Non-Invasive Method for Collecting Buccal DNA from Free-Ranging Non-Human Primates. bioRxiv 2020. [CrossRef]

132. Simons, N.D.; Lorenz, J.G.; Sheeran, L.K.; Li, J.H.; Xia, D.P.; Wagner, R.S. Noninvasive saliva collection for DNA analyses from free-ranging Tibetan Macaques (Macaca thibetana). Am. J. Primatol. 2012. [CrossRef] [PubMed]

133. Smiley Evans, T.; Barry, P.A.; Gilardi, K.V.; Goldstein, T.; Deere, J.D.; Fike, J.; Yee, J.; Ssebide, B.J.; Karmacharya, D.; Cranfield, M.R.; et al. Optimization of a Novel Non-invasive Oral Sampling Technique for Zoonotic Pathogen Surveillance in Nonhuman Primates. PLoS Negl. Trop. Dis. 2015, 9, e0003813. [CrossRef] [PubMed] 
134. Inoue, E.; Inoue-Murayama, M.; Takenaka, O.; Nishida, T. Wild chimpanzee infant urine and saliva sampled noninvasively usable for DNA analyses. Primates 2007, 48, 156-159. [CrossRef] [PubMed]

135. Hayakawa, S.; Takenaka, O. Urine as another potential source for template DNA in polymerase chain reaction (PCR). Am. J. Primatol. 1999, 48, 299-304. [CrossRef]

136. Figueiredo, M.A.P.; Di Santi, S.M.; Manrique, W.G.; André, M.R.; Machado, R.Z. Serological and molecular techniques applied for identification of Plasmodium spp. in blood samples from nonhuman primates. Rev. Bras. Parasitol. Vet. 2018, 27, 363-376. [CrossRef] [PubMed]

137. Taberlet, P.; Waits, L.P.; Luikart, G. Noninvasive genetic sampling: Look before you leap. Trends. Ecol. Evol. 1999, 14, 323-327. [CrossRef]

138. Dai, Y.; Lin, Q.; Fang, W.; Zhou, X.; Chen, X. Noninvasive and nondestructive sampling for avian microsatellite genotyping: A case study on the vulnerable Chinese Egret (Egretta eulophotes). Avian Res. 2015, 6, 24. [CrossRef]

139. Segelbacher, G. Noninvasive genetic analysis in birds: Testing reliability of feather samples. Mol. Ecol. Notes 2002, 2, 367-369. [CrossRef]

140. Knutie, S.A.; Gotanda, K.M. A Non-invasive Method to Collect Fecal Samples from Wild Birds for Microbiome Studies. Microb. Ecol. 2018, 76, 851-855. [CrossRef]

141. Acevedo-Whitehouse, K.; Rocha-Gosselin, A.; Gendron, D. A novel non-invasive tool for disease surveillance of free-ranging whales and its relevance to conservation programs. Anim. Conserv. 2010, 13, 217-225. [CrossRef]

142. Foote, A.D.; Thomsen, P.F.; Sveegaard, S.; Wahlberg, M.; Kielgast, J.; Kyhn, L.A.; Salling, A.B.; Galatius, A.; Orlando, L.; Gilbert, M.T. Investigating the potential use of environmental DNA (eDNA) for genetic monitoring of marine mammals. PLoS ONE 2012, 7, e41781. [CrossRef] [PubMed]

143. Wu, Q.; Conway, J.; Phillips, K.M.; Stolen, M.; Durden, W.N.; Fauquier, D.; McFee, W.E.; Schwacke, L. Detection of Brucella spp. in bottlenose dolphins Tursiops truncatus by a real-time PCR using blowhole swabs. Dis. Aquat. Organ. 2016, 120, 241-244. [CrossRef]

144. Dufresnes, C.; Remollino, N.; Stoffel, C.; Manz, R.; Weber, J.-M.; Fumagalli, L. Two decades of non-invasive genetic monitoring of the grey wolves recolonizing the Alps support very limited dog introgression. Sci. Rep. 2019, 9, 148. [CrossRef] [PubMed]

145. Granroth-Wilding, H.; Primmer, C.; Lindqvist, M.; Poutanen, J.; Thalmann, O.; Aspi, J.; Harmoinen, J.; Kojola, I.; Laaksonen, T. Non-invasive genetic monitoring involving citizen science enables reconstruction of current pack dynamics in a re-establishing wolf population. BMC Ecol. 2017, 17, 44. [CrossRef] [PubMed]

146. Biggs, J.; Ewald, N.; Valentini, A.; Gaboriaud, C.; Dejean, T.; Griffiths, R.A.; Foster, J.; Wilkinson, J.W.; Arnell, A.; Brotherton, P.; et al. Using eDNA to develop a national citizen science-based monitoring programme for the great crested newt (Triturus cristatus). Biol. Conserv. 2015, 183, 19-28. [CrossRef]

147. Santas, A.J.; Persaud, T.; Wolfe, B.A.; Bauman, J.M. Noninvasive Method for a Statewide Survey of Eastern Hellbenders Cryptobranchus alleganiensis Using Environmental DNA. Int. J. Zool. 2013, 2013, 174056. [CrossRef]

148. Piaggio, A.J.; Engeman, R.M.; Hopken, M.W.; Humphrey, J.S.; Keacher, K.L.; Bruce, W.E.; Avery, M.L. Detecting an elusive invasive species: A diagnostic PCR to detect Burmese python in Florida waters and an assessment of persistence of environmental DNA. Mol. Ecol. Resour. 2014, 14, 374-380. [CrossRef]

149. Klymus, K.E.; Richter, C.A.; Chapman, D.C.; Paukert, C. Quantification of eDNA shedding rates from invasive bighead carp Hypophthalmichthys nobilis and silver carp Hypophthalmichthys Molit. Biol. Conserv. 2015, 183, 77-84. [CrossRef]

150. Wilcox, T.M.; McKelvey, K.S.; Young, M.K.; Jane, S.F.; Lowe, W.H.; Whiteley, A.R.; Schwartz, M.K. Robust Detection of Rare Species Using Environmental DNA: The Importance of Primer Specificity. PLoS ONE 2013, 8, e59520. [CrossRef]

151. Piggott, M.P.; Bellemain, E.; Taberlet, P.; Taylor, A.C. A Multiplex Pre-Amplification Method that Significantly Improves Microsatellite Amplification and Error Rates for Faecal DNA in Limiting Conditions. Conserv. Genet. 2004, 5, 417-420. [CrossRef]

152. Taberlet, P.; Luikart, G. Non-invasive genetic sampling and individual identification. Biol. J. Linn. Soc. 1999, 68, 41-55. [CrossRef]

153. Taberlet, P.; Griffin, S.; Goossens, B.; Questiau, S.; Manceau, V.; Escaravage, N.; Waits, L.P.; Bouvet, J. Reliable genotyping of samples with very low DNA quantities using PCR. Nucleic Acids Res. 1996, 24, 3189-3194. [CrossRef]

154. Irwin, M.T.; Samonds, K.E.; Raharison, J.-L.; Wright, P.C. Lemur Latrines: Observations of Latrine Behavior in Wild Primates and Possible Ecological Significance. J. Mammal. 2004, 85, 420-427. [CrossRef]

155. Smiley, T.; Spelman, L.; Lukasik-Braum, M.; Mukherjee, J.; Kaufman, G.; Akiyoshi, D.E.; Cranfield, M. Noninvasive saliva collection techniques for free-ranging mountain gorillas and captive eastern gorillas. J. Zoo Wildl Med. 2010, 41, 201-209. [CrossRef] [PubMed]

156. Santos, A.; Souza, A.M.; Bueno, M.G.; Catao-Dias, J.L.; Toma, H.K.; Pissinati, A.; Molina, C.V.; Kierulff, M.C.M.; Silva, D.G.F.; Almosny, N.R.P. Molecular detection of Borrelia burgdorferi in free-living golden headed lion tamarins (Leontopithecus chrysomelas) in Rio de Janeiro, Brazil. Rev. Inst. Med. Trop. Sao Paulo 2018, 60, e53. [CrossRef]

157. Lilenbaum, W.; Varges, R.; Moraes, I.A.; Ferreira, A.M.; Pissinatti, A. Leptospiral antibodies in captive lion tamarins (Leontopithecus sp) in Brazil. Vet. J. 2005, 169, 462-464. [CrossRef] [PubMed]

158. Molina, C.V.; Heinemann, M.B.; Kierulff, C.; Pissinatti, A.; da Silva, T.F.; de Freitas, D.G.; de Souza, G.O.; Miotto, B.A.; Cortez, A.; Semensato, B.P.; et al. Leptospira spp., rotavirus, norovirus, and hepatitis E virus surveillance in a wild invasive golden-headed lion tamarin (Leontopithecus chrysomelas; Kuhl, 1820) population from an urban park in Niterói, Rio de Janeiro, Brazil. Am. J. Primatol. 2019, 81, e22961. [CrossRef] [PubMed] 
159. Romero, M.H.; Astudillo, M.; Sánchez, J.A.; González, L.M.; Varela, N. Anticuerpos contra Leptospira sp. en primates neotropicales y trabajadores de un zoológico colombiano/Leptospiral antibodies in a Colombian zoo's Neotropical primates and workers. Rev. Salud Pública 2011, 13, 814-823. [CrossRef] [PubMed]

160. Pérez-Brígido, C.D.; Romero-Salas, D.; Sánchez-Montes, S.; Hermida-Lagunes, J.; Ochoa, J.L.; Canales-Espinosa, D.; Cruz-Romero, A. Serologic survey of Leptospira spp. in captive animals from vVeracruz, Mexico. J. Zoo Wildl. Med. 2020, 51, 222-227. [CrossRef]

161. Perolat, P.; Poingt, J.P.; Vie, J.C.; Jouaneau, C.; Baranton, G.; Gysin, J. Occurrence of severe leptospirosis in a breeding colony of squirrel monkeys. Am. J. Trop. Med. Hyg 1992, 46, 538-545. [CrossRef]

162. Pinna, M.H.; Martins, G.; Pinheiro, A.C.; Almeida, D.S.; Oriá, A.P.; Lilenbaum, W. Detection of anti-Leptospira antibodies in captive nonhuman primates from Salvador, Brazil. Am. J. Primatol. 2012, 74, 8-11. [CrossRef]

163. Romero, M.H.; Astudillo, M.; Sánchez, J.A.; González, L.M.; Varela, N. Títulos de anticuerpos contra Leptospira sp., en primates del zoológico Matecaña, Pereira, Colombia. Rev.MVZ Córdoba 2012, 17, 3224-3230. [CrossRef]

164. Scarcelli, E.; Piatti, R.M.; Fedullo, J.D.L.; Simon, F.; Cardoso, M.V.; Castro, V.; Miyashiro, S.; Genovez, M.É. Leptospira spp detection by Polymerase Chain Reaction (PCR) in clinical samples of captive black-capped Capuchin monkey (Cebus apella). Braz. J. Microbiol. 2003, 34, 143-146. [CrossRef]

165. Szonyi, B.; Agudelo-Flórez, P.; Ramírez, M.; Moreno, N.; Ko, A.I. An outbreak of severe leptospirosis in capuchin (Cebus) monkeys. Vet. J. 2011, 188, 237-239. [CrossRef]

166. Adams, M.R.; Lewis, J.C.; Bullock, B.C. Hemobartonellosis in squirrel monkeys (Saimiri sciureus) in a domestic breeding colony: Case report and preliminary study. Lab. Anim. Sci. 1984, 34, 82-85. [PubMed]

167. Bonato, L.; Figueiredo, M.A.P.; Gonçalves, L.R.; Machado, R.Z.; André, M.R. Occurrence and molecular characterization of Bartonella spp. and hemoplasmas in neotropical primates from Brazilian Amazon. Comp. Immunol. Microbiol. Infect. Dis. 2015, 42, 15-20. [CrossRef] [PubMed]

168. Cubilla, M.P.; Santos, L.C.; de Moraes, W.; Cubas, Z.S.; Leutenegger, C.M.; Estrada, M.; Vieira, R.F.C.; Soares, M.J.; Lindsay, L.L.; Sykes, J.E.; et al. Occurrence of hemotropic mycoplasmas in non-human primates (Alouatta caraya, Sapajus nigritus and Callithrix jacchus) of southern Brazil. Comp. Immunol. Microbiol. Infect. Dis. 2017, 52, 6-13. [CrossRef] [PubMed]

169. de Melo, C.M.F.; Daneze, E.R.; Mendes, N.S.; de Souza Ramos, I.A.; Morales-Donoso, J.A.; Fernandes, S.J.; Machado, R.Z.; André, M.R.; da Rosa Sobreira, M.F. Genetic diversity and hematological and biochemical alterations in Alouatta primates naturally infected with hemoplasmas in Brazil. Comp. Immunol. Microbiol. Infect. Dis. 2019, 63, 104-111. [CrossRef]

170. Neimark, H.; Barnaud, A.; Gounon, P.; Michel, J.-C.; Contamin, H. The putative haemobartonella that influences Plasmodium falciparum parasitaemia in squirrel monkeys is a haemotrophic mycoplasma. Microbes Infect. 2002, 4, 693-698. [CrossRef]

171. Ramalho, A.C.; Guerra, R.R.; Mongruel, A.C.B.; Vidotto, O.; Lucena, R.B.; Guerra, M.V.S.F.; Vieira, T.S.W.J.; Vieira, R.F.C. Mycoplasma sp. infection in captive Marcgrave's capuchin monkeys (Sapajus flavius). Comp. Immunol. Microbiol. Infect. Dis. 2017, 51, 34-36. [CrossRef] [PubMed]

172. Santos, L.C.; Cubilla, M.P.; de Moraes, W.; Cubas, Z.S.; Oliveira, M.J.; Estrada, M.; Leutenegger, C.M.; Sykes, J.E.; Lindsay, L.L.; Marcondes, M.; et al. Hemotropic mycoplasma in a free-ranging black howler monkey (Alouatta caraya) in Brazil. J. Wildl. Dis. 2013, 49, 728-731. [CrossRef] [PubMed]

173. Hill, W.C.O. Report of the Society's Prosector for the year 1952. Proc.Zool. Soc. Lond. 1953, 123, 227e251. [CrossRef]

174. Bueno, M.G. Pesquisa de Leishmania spp. e Plasmodium spp. em primatas neotropicais provenientes de regiões de Mata Atlântica e Amazônia impactadas por ações antrópicas: Investigação in situ e ex situ; Universidad de Sao Paulo: Sao Paulo, Brazil, 2012.

175. Voltarelli, E.M.; Arraes, S.; Perles; Lonardoni, M.V.C.; Teodoro, U.; Silveira, T.G.V. Serological survey for Leishmania sp. infection in wild animals from the municipality of Maringá, Paraná state, Brazil. J. Venom. Anim. Toxins Incl. Trop. Dis. 2009, 15, 732-744. [CrossRef]

176. Acardi, S.A.; Rago, M.V.; Liotta, D.J.; Fernandez-Duque, E.; Salomón, O.D. Leishmania (Viannia) DNA detection by PCR-RFLP and sequencing in free-ranging owl monkeys (Aotus azarai azarai) from Formosa, Argentina. Vet. Parasitol. 2013, 193, $256-259$. [CrossRef] [PubMed]

177. Cuba-Cuba, C.A.; Marsden, P.D. Marmosets in New World leishmaniasis research. Medicina 1993, 53, 419-423. [PubMed]

178. Lima, V.M.; Santiago, M.E.; Sanches Lda, C.; Lima, B.D. Molecular diagnosis of Leishmania amazonensis in a captive spider monkey in Bauru, São Paulo, Brazil. J. Zoo Wildl. Med. 2012, 43, 943-945. [CrossRef]

179. Baker, J.R. Protozoa of Tissues and Blood (Other than the Haemosporina). In Pathology of Simian Primates Part II: Infectious and Parasitic Diseases; Fiennes, R., Ed.; Karger: Basel, Switzerland, 1972; pp. 29-56.

180. Paiz, L.M.; Fornazari, F.; Menozzi, B.D.; Oliveira, G.C.; Coiro, C.J.; Teixeira, C.R.; da Silva, V.M.; Donalisio, M.R.; Langoni, H. Serological Evidence of Infection by Leishmania (Leishmania) infantum (Synonym: Leishmania (Leishmania) chagasi) in FreeRanging Wild Mammals in a Nonendemic Region of the State of São Paulo, Brazil. Vector Borne Zoonotic Dis. 2015, 15, 667-673. [CrossRef]

181. Rovirosa-Hernández Mde, J.; Cortes-Ortíz, L.; García-Orduña, F.; Guzmán-Gómez, D.; López-Monteon, A.; Caba, M.; RamosLigonio, A. Seroprevalence of Trypanosoma cruzi and Leishmania mexicana in free-ranging howler monkeys in southeastern Mexico. Am. J. Primatol. 2013, 75, 161-169. [CrossRef]

182. Fandeur, T.; Volney, B.; Peneau, C.; de Thoisy, B. Monkeys of the rainforest in French Guiana are natural reservoirs for P. brasilianum /P. malariae malaria. Parasitology 2000, 120, 11-21. [CrossRef] 
183. Costa, D.C.; Cunha, V.P.d.; Assis, G.M.P.d.; Souza Junior, J.C.d.; Hirano, Z.M.B.; Arruda, M.E.d.; Kano, F.S.; Carvalho, L.H.; Brito, C.F.A.d. Plasmodium simium/Plasmodium vivax infections in southern brown howler monkeys from the Atlantic Forest. Mem. Inst. Oswaldo Cruz 2014, 109, 641-653. [CrossRef]

184. de Castro Duarte, A.M.; Malafronte Rdos, S.; Cerutti, C., Jr.; Curado, I.; de Paiva, B.R.; Maeda, A.Y.; Yamasaki, T.; Summa, M.E.; Neves Ddo, V.; de Oliveira, S.G.; et al. Natural Plasmodium infections in Brazilian wild monkeys: Reservoirs for human infections? Acta Trop. 2008, 107, 179-185. [CrossRef] [PubMed]

185. Duarte, A.M.; Porto, M.A.; Curado, I.; Malafronte, R.S.; Hoffmann, E.H.; de Oliveira, S.G.; da Silva, A.M.; Kloetzel, J.K.; Gomes Ade, C. Widespread occurrence of antibodies against circumsporozoite protein and against blood forms of Plasmodium vivax, P. falciparum and P. malariae in Brazilian wild monkeys. J. Med. Primatol. 2006, 35, 87-96. [CrossRef]

186. Volney, B.; Pouliquen, J.F.; De Thoisy, B.; Fandeur, T. A sero-epidemiological study of malaria in human and monkey populations in French Guiana. Acta Trop. 2002, 82, 11-23. [CrossRef]

187. Yamasaki, T.; Duarte, A.M.; Curado, I.; Summa, M.E.; Neves, D.V.; Wunderlich, G.; Malafronte, R.S. Detection of etiological agents of malaria in howler monkeys from Atlantic Forests, rescued in regions of São Paulo city, Brazil. J. Med. Primatol. 2011, 40, 392-400. [CrossRef] [PubMed]

188. Araújo, M.S.; Messias, M.R.; Figueiró, M.R.; Gil, L.H.S.; Probst, C.M.; Vidal, N.M.; Katsuragawa, T.H.; Krieger, M.A.; Silva, L.H.P.d.; Ozaki, L.S. Natural Plasmodium infection in monkeys in the state of Rondonia (Brazilian Western Amazon). Malar. J. 2013, 12, 180. [CrossRef] [PubMed]

189. Deane, L.M. Simian malaria in Brazil. Mem. Inst. Oswaldo Cruz 1992, 87, 1-20. [CrossRef] [PubMed]

190. de Alvarenga, D.A.M.; de Pina-Costa, A.; de Sousa, T.N.; Pissinatti, A.; Zalis, M.G.; Suaréz-Mutis, M.C.; Lourenço-de-Oliveira, R.; Brasil, P.; Daniel-Ribeiro, C.T.; de Brito, C.F.A. Simian malaria in the Brazilian Atlantic forest: First description of natural infection of capuchin monkeys (Cebinae subfamily) by Plasmodium Simium. Malar. J. 2015, 14, 81. [CrossRef] [PubMed]

191. Alvarenga, D.A.M.; Pina-Costa, A.; Bianco, C.; Moreira, S.B.; Brasil, P.; Pissinatti, A.; Daniel-Ribeiro, C.T.; Brito, C.F.A. New potential Plasmodium brasilianum hosts: Tamarin and marmoset monkeys (family Callitrichidae). Malar. J. 2017, 16, 71. [CrossRef]

192. de Arruda, M.; Nardin, E.H.; Nussenzweig, R.S.; Cochrane, A.H. Sero-epidemiological studies of malaria in Indian tribes and monkeys of the Amazon Basin of Brazil. Am. J. Trop. Med. Hyg. 1989, 41, 379-385. [CrossRef]

193. Abreu, F.V.S.d.; Santos, E.d.; Mello, A.R.L.; Gomes, L.R.; Alvarenga, D.A.M.d.; Gomes, M.Q.; Vargas, W.P.; Bianco-Júnior, C.; Pina-Costa, A.d.; Teixeira, D.S.; et al. Howler monkeys are the reservoir of malarial parasites causing zoonotic infections in the Atlantic forest of Rio de Janeiro. PLoS Negl. Trop. Dis. 2019, 13, e0007906. [CrossRef]

194. Alvarado-Esquivel, C.; Gayosso-Dominguez, E.A.; Villena, I.; Dubey, J.P. Seroprevalence of Toxoplasma gondii infection in captive mammals in three zoos in Mexico City, Mexico. J. Zoo Wildl. Med.. 2013, 44, 803-806. [CrossRef]

195. Andrade, M.C.R.; Coelho, J.M.C.d.O.; Amendoeira, M.R.R.; Vicente, R.T.; Cardoso, C.V.P.; Ferreira, P.C.B.; Marchevsky, R.S. Toxoplasmosis in squirrel monkeys: Histological and immunohistochemical analysis. Ciênc. Rural 2007, 37, 1724-1727. [CrossRef]

196. Antoniassi, N.A.; Boabaid, F.M.; Souza, R.L.; Nakazato, L.; Pimentel, M.F.; Filho, J.O.; Pescador, C.A.; Driemeier, D.; Colodel, E.M. Granulomatous meningoencephalitis due to toxoplasma gondii in a black-headed night monkey (Aotus nigriceps). J. Zoo Wildl. Med. 2011, 42, 118-120. [CrossRef] [PubMed]

197. Bouer, A.; Werther, K.; Machado, R.Z.; Nakaghi, A.C.; Epiphanio, S.; Catão-Dias, J.L. Detection of anti-Toxoplasma gondii antibodies in experimentally and naturally infected non-human primates by Indirect Fluorescence Assay (IFA) and indirect ELISA. Rev. Bras. De Parasitol. Vet. 2010, 19, 26-31. [CrossRef]

198. Cadavid, A.P.; Cañas, L.; Estrada, J.J.; Ramirez, L.E. Prevalence of anti-Toxoplasma gondii antibodies in Cebus spp in the Santa Fe Zoological Park of Medellín, Colombia. J. Med. Primatol. 1991, 20, 259-261. [CrossRef]

199. Carme, B.; Aznar, C.; Motard, A.; Demar, M.; de Thoisy, B. Serologic survey of Toxoplasma gondii in noncarnivorous free-ranging neotropical mammals in French Guiana. Vector Borne Zoonotic Dis. 2002, 2, 11-17. [CrossRef]

200. Carme, B.; Ajzenberg, D.; Demar, M.; Simon, S.; Dardé, M.L.; Maubert, B.; de Thoisy, B. Outbreaks of toxoplasmosis in a captive breeding colony of squirrel monkeys. Vet. Parasitol. 2009, 163, 132-135. [CrossRef]

201. Cedillo-Peláez, C.; Rico-Torres, C.P.; Salas-Garrido, C.G.; Correa, D. Acute toxoplasmosis in squirrel monkeys (Saimiri sciureus) in Mexico. Vet. Parasitol. 2011, 180, 368-371. [CrossRef]

202. Dietz, H.H.; Henriksen, P.; Bille-Hansen, V.; Henriksen, S.A. Toxoplasmosis in a colony of New World monkeys. Vet. Parasitol. 1997, 68, 299-304. [CrossRef]

203. de Thoisy, B.; Vogel, I.; Reynes, J.-M.; Pouliquen, J.-F.; Carme, B.; Kazanji, M.; Vié, J.-C. Health evaluation of translocated free-ranging primates in French Guiana. Am. J. Primatol. 2001, 54, 1-16. [CrossRef] [PubMed]

204. Epiphanio, S.; Guimarães, M.A.; Fedullo, D.L.; Correa, S.H.; Catão-Dias, J.L. Toxoplasmosis in golden-headed lion tamarins (Leontopithecus chrysomelas) and emperor marmosets (Saguinus imperator) in captivity. J. Zoo Wildl. Med. 2000, 31, $231-235$.

205. Epiphanio, S.; Sá, L.R.; Teixeira, R.H.; Catão-Dias, J.L. Toxoplasmosis in a wild-caught black lion tamarin (Leontopithecus chrysopygus). Vet. Rec. 2001, 149, 627-628. [CrossRef] [PubMed]

206. Gyimesi, Z.S.; Lappin, M.R.; Dubey, J.P. Application of assays for the diagnosis of toxoplasmosis in a colony of woolly monkeys (Lagothrix lagotricha). J. Zoo Wildl. Med. 2006, 37, 276-280. [CrossRef]

207. Inoue, M. Acute toxoplasmosis in squirrel monkeys. J. Vet. Med. Sci. 1997, 59, 593-595. [CrossRef] [PubMed]

208. Juan-Sallés, C.; Prats, N.; Marco, A.J.; Ramos-Vara, J.A.; Borrás, D.; Fernández, J. Fatal acute toxoplasmosis in three golden lion tamarins (Leontopithecus rosalia). J. Zoo Wildl. Med. 1998, 29, 55-60. [PubMed] 
209. Garcia, J.L.; Svoboda, W.K.; Chryssafidis, A.L.; de Souza Malanski, L.; Shiozawa, M.M.; de Moraes Aguiar, L.; Teixeira, G.M.; Ludwig, G.; da Silva, L.R.; Hilst, C.; et al. Sero-epidemiological survey for toxoplasmosis in wild New World monkeys (Cebus spp.; Alouatta caraya) at the Paraná river basin, Paraná State, Brazil. Vet. Parasitol. 2005, 133, 307-311. [CrossRef] [PubMed]

210. Molina, C.V.; Catão-Dias, J.L.; Ferreira Neto, J.S.; Vasconcellos, S.A.; Gennari, S.M.; do Valle Rdel, R.; de Souza, G.O.; de Morais, Z.M.; Vitaliano, S.N.; Strefezzi Rde, F.; et al. Sero-epidemiological survey for brucellosis, leptospirosis, and toxoplasmosis in free-ranging Alouatta caraya and Callithrix penicillata from São Paulo State, Brazil. J. Med Primatol. 2014, 43, 197-201. [CrossRef] [PubMed]

211. Ferreira, D.R.; Ribeiro, V.O.; Laroque, P.O.; Wagner, P.G.; Pinheiro Júnior, J.W.; Silva, J.C.; Dubey, J.P.; Rêgo, E.W.; Mota, R.A. Risk factors associated with Toxoplasma gondii infection in captive Sapajus spp. Am. J. Primatol. 2015, 77, 558-562. [CrossRef]

212. Fiorello, C.V.; Heard, D.J.; Heller, H.L.; Russell, K. Medical management of Toxoplasma meningitis in a white-throated capuchin (Cebus capucinus). J. Zoo Wildl. Med. 2006, 37, 409-412. [CrossRef]

213. Lourenço-de-Oliveira, R.; Deane, L.M. Simian malaria at two sites in the Brazilian Amazon. I-The infection rates of Plasmodium brasilianum in non-human primates. Mem Inst. Oswaldo Cruz 1995, 90, 331-339. [CrossRef]

214. Pardini, L.; Dellarupe, A.; Bacigalupe, D.; Quiroga, M.A.; Moré, G.; Rambeaud, M.; Basso, W.; Unzaga, J.M.; Schares, G.; Venturini, M.C. Isolation and molecular characterization of Toxoplasma gondii in a colony of captive black-capped squirrel monkeys (Saimiri boliviensis). Parasitol Int. 2015, 64, 587-590. [CrossRef]

215. Paula, N.F.; Dutra, K.S.; Oliveira, A.R.; Santos, D.O.D.; Rocha, C.E.V.; Vitor, R.W.A.; Tinoco, H.P.; Costa, M.; Paixão, T.A.D.; Santos, R.L. Host range and susceptibility to Toxoplasma gondii infection in captive neotropical and Old-world primates. J. Med. Primatol.. 2020, 49, 202-210. [CrossRef]

216. Pertz, C.; Dubielzig, R.R.; Lindsay, D.S. Fatal Toxoplasma gondii infection in golden lion tamarins (Leontopithecus rosalia rosalia). J. Zoo Wildl. Med. 1997, 28, 491-493. [PubMed]

217. Santos, S.V.; Strefezzi, R.F.; Pissinatti, A.; Kanamura, C.T.; Takakura, C.F.; Duarte, M.I.; Catão-Dias, J.L. Detection of Toxoplasma gondii in two southern Wooly spider monkeys (Brachyteles arachnoides-Geoffroy, 1806) from the Rio de Janeiro primate center, Brazil. J. Med. Primatol. 2014, 43, 125-129. [CrossRef] [PubMed]

218. Santos, S.V.; Pena, H.F.J.; Talebi, M.G.; Teixeira, R.H.F.; Kanamura, C.T.; Diaz-Delgado, J.; Gennari, S.M.; Catão-Dias, J.L. Fatal toxoplasmosis in a southern muriqui (Brachyteles arachnoides) from São Paulo state, Brazil: Pathological, immunohistochemical, and molecular characterization. J. Med. Primatol. 2018, 47, 124-127. [CrossRef]

219. Stuart, M.D.; Pendergast, V.; Rumfelt, S.; Pierberg, S.; Greenspan, L.L.; Glander, K.E.; Clarke, M.R. Parasites of wild howlers (Alouatta spp.). Int. J. Primatol. 1998, 19, 493-512. [CrossRef]

220. Soto-Calderón, I.D.; Acevedo-Garcés, Y.A.; Álvarez-Cardona, J.; Hernández-Castro, C.; García-Montoya, G.M. Physiological and parasitological implications of living in a city: The case of the white-footed tamarin (Saguinus leucopus). Am. J. Primatol. 2016, 78, 1272-1281. [CrossRef] [PubMed]

221. Martínez, M.F.; Kowalewski, M.M.; Salomón, O.D.; Schijman, A.G. Molecular characterization of trypanosomatid infections in wild howler monkeys (Alouatta caraya) in northeastern Argentina. Int. J. Parasitol. Parasites Wildl. 2016, 5, 198-206. [CrossRef] [PubMed]

222. Minuzzi-Souza, T.T.; Nitz, N.; Knox, M.B.; Reis, F.; Hagström, L.; Cuba, C.A.; Hecht, M.M.; Gurgel-Gonçalves, R. Vector-borne transmission of Trypanosoma cruzi among captive Neotropical primates in a Brazilian zoo. Parasit Vectors 2016, 9, 39. [CrossRef] [PubMed]

223. Hoare, C.A. The Trypanosomes of Mammals: A Zoological Monograph; Blackwell Scientific Publications: Hoboken, NJ, USA; The University of Michigan: Ann Arbor, MI, USA, 1972.

224. Sousa, O.E.; Rossan, R.N.; Baerg, D.C. The prevalence of trypanosomes and microfilariae in Panamanian monkeys. Am. J. Trop Med. Hyg. 1974, 23, 862-868. [CrossRef] [PubMed]

225. Lisboa, C.V.; Mangia, R.H.; Rubião, E.; de Lima, N.R.; das Chagas Xavier, S.C.; Picinatti, A.; Ferreira, L.F.; Fernandes, O.; Jansen, A.M. Trypanosoma cruzi transmission in a captive primate unit, Rio de Janeiro, Brazil. Acta Trop. 2004, 90, 97-106. [CrossRef]

226. Marcili, A.; Valente, V.C.; Valente, S.A.; Junqueira, A.C.V.; Silva, F.M.d.; Pinto, A.Y.d.N.; Naiff, R.D.; Campaner, M.; Coura, J.R.; Camargo, E.P.; et al. Trypanosoma cruzi in Brazilian Amazonia: Lineages TCI and TCIIa in wild primates, Rhodnius spp. and in humans with Chagas disease associated with oral transmission. Int. J. Parasitol. 2009, 39, 615-623. [CrossRef]

227. Kerr, C.L.; Bhattacharyya, T.; Xavier, S.C.; Barros, J.H.; Lima, V.S.; Jansen, A.M.; Miles, M.A. Lineage-specific serology confirms Brazilian Atlantic forest lion tamarins, Leontopithecus chrysomelas and Leontopithecus rosalia, as reservoir hosts of Trypanosoma cruzi II (TcII). Parasit Vectors 2016, 9, 584. [CrossRef]

228. Monteiro, R.V.; Dietz, J.M.; Jansen, A.M. The impact of concomitant infections by Trypanosoma cruzi and intestinal helminths on the health of wild golden and golden-headed lion tamarins. Res. Vet. Sci. 2010, 89, 27-35. [CrossRef] [PubMed]

229. Dunn, F.L.; Lambrecht, F.L.; Duplessis, R. Trypanosomes of south american monkeys and marmosets. Am. J. Trop. Med. Hyg. 1963, 12, 524-534. [CrossRef] [PubMed]

230. Ziccardi, M.; Lourenço-de-Oliveira, R. The infection rates of trypanosomes in squirrel monkeys at two sites in the Brazilian Amazon. Mem. Inst. Oswaldo Cruz 1997, 92, 465-470. [CrossRef]

231. Ziccardi, M.; Lourenço-De-Oliveira, R.; Lainson, R.; Brígido, M.C.; Muniz, J.A. Trypanosomes of non-human primates from the National Centre of Primates, Ananindeua, State of Pará, Brazil. Mem. Inst. Oswaldo Cruz 2000, 95, 157-159. [CrossRef] [PubMed] 
232. Deane, L.M. Tripanosomídeos de mamíferos da região amazônica. IV. Hemoscopia e xenodiagnóstico de animais silvestres da estrada Belém-Brasília. Rev. Inst. Med. Trop. S Paulo. 1967, 9, 143-148. [PubMed]

233. Leônidas de Mello, D. Tripanosomideos de mamíferos da regiao amazonica. Rev. Inst. Med. Trop S Paulo 1961, 3, 61-70.

234. Erkenswick, G.A.; Watsa, M.; Gozalo, A.S.; Dmytryk, N.; Parker, P.G. Temporal and demographic blood parasite dynamics in two free-ranging neotropical primates. Int. J. Parasitol. Parasites Wildl. 2017, 6, 59-68. [CrossRef]

235. Tenório, M.S.; Oliveira e Sousa, L.; Alves-Martin, M.F.; Paixão, M.S.; Rodrigues, M.V.; Starke-Buzetti, W.A.; Araújo Junior, J.P.; Lucheis, S.B. Molecular identification of trypanosomatids in wild animals. Vet. Parasitol. 2014, 203, 203-206. [CrossRef]

236. Ayala, F. Presencia de un hemoflagelado semejante al Trypanosoma rangeli Tejera 1920, en el mono Saimiri boliviensis, en la Región Amazona, Peru. Rev. Inst. Med. Trop. S Paulo 1964, 6, 47-50.

237. Maia da Silva, F.; Naiff, R.D.; Marcili, A.; Gordo, M.; D’Affonseca Neto, J.A.; Naiff, M.F.; Franco, A.M.; Campaner, M.; Valente, V.; Valente, S.A.; et al. Infection rates and genotypes of Trypanosoma rangeli and T. cruzi infecting free-ranging Saguinus bicolor (Callitrichidae), a critically endangered primate of the Amazon Rainforest. Acta Trop. 2008, 107, 168-173. [CrossRef]

238. Batista, P.M.; Andreotti, R.; Chiang, J.O.; Ferreira, M.S.; Vasconcelos, P.F. Seroepidemiological monitoring in sentinel animals and vectors as part of arbovirus surveillance in the state of Mato Grosso do Sul, Brazil. Rev. Soc. Bras. Med. Trop. 2012, 45, 168-173. [CrossRef] [PubMed]

239. Karesh, W.; Wallace, R.; Painter, L.; Rumiz, D.; Braselton, W.; Dierenfeld, E.; Puche, H. Immobilization and health assessment of free-ranging black spider monkeys (Ateles paniscus chamek). Am. J. Primatol. 1998, 44, 107-123. [CrossRef]

240. Laroque, P.O.; Valença-Montenegro, M.M.; Ferreira, D.R.A.; Chiang, J.O.; Cordeiro, M.T.; Vasconcelos, P.F.C.; Silva, J.C.R. Levantamento soroepidemiológico para arbovírus em macaco-prego-galego (Cebus flavius) de vida livre no estado da Paraíba e em macaco-prego (Cebus libidinosus) de cativeiro do nordeste do Brasil. Pesq. Vet. Bras. 2014, 34, 462-468. [CrossRef]

241. Hoch, A.L.; Peterson, N.E.; LeDuc, J.W.; Pinheiro, F.P. An Outbreak of Mayaro Virus Disease in Belterra, Brazil. Am. J. Trop. Med. Hyg. 1981, 30, 689. [CrossRef] [PubMed]

242. Seymour, C.; Peralta, P.H.; Montgomery, G.G. Serologic evidence of natural togavirus infections in Panamanian sloths and other vertebrates. Am. J. Trop. Med. Hyg. 1983, 32, 854-861. [CrossRef]

243. Talarmin, A.; Chandler, L.J.; Kazanji, M.; de Thoisy, B.; Debon, P.; Lelarge, J.; Labeau, B.; Bourreau, E.; Vie, J.C.; Shope, R.E.; et al. Mayaro virus fever in French Guiana: Isolation, identification, and seroprevalence. Am. J. Trop. Med. Hyg. 1998, 59, $452-456$. [CrossRef]

244. Diaz, L.A.; Diaz Mdel, P.; Almiron, W.R.; Contigiani, M.S. Infection by UNA virus (Alphavirus; Togaviridae) and risk factor analysis in black howler monkeys (Alouatta caraya) from Paraguay and Argentina. Trans. R Soc. Trop. Med. Hyg. 2007, 101, 1039-1041. [CrossRef]

245. Wells, E.A.; D'Alessandro, A.; Morales, G.A.; Angel, D. Mammalian wildlife diseases as hazards to man and livestock in an area of the Llanos Orientales of Colombia. J. Wildl. Dis 1981, 17, 153-162. [CrossRef] [PubMed]

246. Catenacci, L.S.; Ferreira, M.; Martins, L.C.; De Vleeschouwer, K.M.; Cassano, C.R.; Oliveira, L.C.; Canale, G.; Deem, S.L.; Tello, J.S.; Parker, P.; et al. Surveillance of Arboviruses in Primates and Sloths in the Atlantic Forest, Bahia, Brazil. EcoHealth 2018, 15, 777-791. [CrossRef]

247. Morales, M.A.; Fabbri, C.M.; Zunino, G.E.; Kowalewski, M.M.; Luppo, V.C.; Enria, D.A.; Levis, S.C.; Calderon, G.E. Detection of the mosquito-borne flaviviruses, West Nile, Dengue, Saint Louis Encephalitis, Ilheus, Bussuquara, and Yellow Fever in free-ranging black howlers (Alouatta caraya) of Northeastern Argentina. PLoS Negl. Trop. Dis. 2017, 11, e0005351. [CrossRef]

248. Abreu, F.V.S.; Delatorre, E.; Dos Santos, A.A.C.; Ferreira-de-Brito, A.; de Castro, M.G.; Ribeiro, I.P.; Furtado, N.D.; Vargas, W.P.; Ribeiro, M.S.; Meneguete, P.; et al. Combination of surveillance tools reveals that Yellow Fever virus can remain in the same Atlantic Forest area at least for three transmission seasons. Mem. Inst. Oswaldo Cruz 2019, 114, e190076. [CrossRef] [PubMed]

249. Auguste, A.J.; Lemey, P.; Pybus, O.G.; Suchard, M.A.; Salas, R.A.; Adesiyun, A.A.; Barrett, A.D.; Tesh, R.B.; Weaver, S.C.; Carrington, C.V. Yellow fever virus maintenance in Trinidad and its dispersal throughout the Americas. J. Virol. 2010, 84, 9967-9977. [CrossRef] [PubMed]

250. Auguste, A.J.; Lemey, P.; Bergren, N.A.; Giambalvo, D.; Moncada, M.; Morón, D.; Hernandez, R.; Navarro, J.-C.; Weaver, S.C. Enzootic transmission of yellow fever virus, Venezuela. Emerg. Infect. Dis. 2015, 21, 99-102. [CrossRef]

251. Bonaldo, M.C.; Gomez, M.M.; Dos Santos, A.A.; Abreu, F.V.S.; Ferreira-de-Brito, A.; Miranda, R.M.; Castro, M.G.; Lourencode-Oliveira, R. Genome analysis of yellow fever virus of the ongoing outbreak in Brazil reveals polymorphisms. Mem. Inst. Oswaldo Cruz 2017, 112, 447-451. [CrossRef]

252. de Almeida, M.A.; Dos Santos, E.; da Cruz Cardoso, J.; da Fonseca, D.F.; Noll, C.A.; Silveira, V.R.; Maeda, A.Y.; de Souza, R.P.; Kanamura, C.; Brasil, R.A. Yellow fever outbreak affecting Alouatta populations in southern Brazil (Rio Grande do Sul State), 2008-2009. Am. J. Primatol. 2012, 74, 68-76. [CrossRef]

253. Leal, S.G.; Romano, A.P.; Monteiro, R.V.; Melo, C.B.; Vasconcelos, P.F.; Castro, M.B. Frequency of histopathological changes in Howler monkeys (Alouatta sp.) naturally infected with yellow fever virus in Brazil. Rev. Soc. Bras. Med. Trop. 2016, 49, 29-33. [CrossRef]

254. Mares-Guia, M.; Horta, M.A.; Romano, A.; Rodrigues, C.D.S.; Mendonca, M.C.L.; Dos Santos, C.C.; Torres, M.C.; Araujo, E.S.M.; Fabri, A.; de Souza, E.R.; et al. Yellow fever epizootics in non-human primates, Southeast and Northeast Brazil (2017 and 2018 ). Parasit Vectors 2020, 13, 90. [CrossRef] 
255. Moreno, E.S.; Rocco, I.M.; Bergo, E.S.; Brasil, R.A.; Siciliano, M.M.; Suzuki, A.; Silveira, V.R.; Bisordi, I.; Souza, R.P. Reemergence of yellow fever: Detection of transmission in the State of Sao Paulo, Brazil, 2008. Rev. Soc. Bras. Med. Trop. 2011, 44, 290-296. [CrossRef]

256. Pinheiro, F.P.; Travassos da Rosa, A.P.; Moraes, M.A. An epidemic of yellow fever in Central Brazil, 1972-1973. II. Ecological studies. Am. J. Trop. Med. Hyg. 1981, 30, 204-211. [CrossRef] [PubMed]

257. Rawlins, S.C.; Hull, B.; Chadee, D.D.; Martinez, R.; LeMaitre, A.; James, F.; Webb, L. Sylvatic yellow fever activity in Trinidad, 1988-1989. Trans. R Soc. Trop. Med. Hyg. 1990, 84, 142-143. [CrossRef]

258. Sallis, E.S.; de Barros, V.L.; Garmatz, S.L.; Fighera, R.A.; Graca, D.L. A case of yellow fever in a brown howler (Alouatta fusca) in Southern Brazil. J. Vet. Diagn. Invest. 2003, 15, 574-576. [CrossRef]

259. Tranquilin, M.V.; Lehmkuhl, R.C.; Maron, A.; da Silva, L.R.; Ziliotto, L.; Seki, M.C.; Salomon, G.R.; de Oliveira Torres Carrasco, A. First report of yellow fever virus in non-human primates in the State of Parana, Brazil. Rev. Soc. Bras. Med. Trop. 2013, 46, 522-524. [CrossRef]

260. Velandia, M.P. La Re-emergencia de la fiebre amarilla en Colombia. Rev. MVZ Córdoba 2004, 9, 459-462. [CrossRef]

261. Almeida, M.A.B.; Santos, E.D.; Cardoso, J.D.C.; Noll, C.A.; Lima, M.M.; Silva, F.A.E.; Ferreira, M.S.; Martins, L.C.; Vasconcelos, P.; Bicca-Marques, J.C. Detection of antibodies against Icoaraci, Ilheus, and Saint Louis Encephalitis arboviruses during yellow fever monitoring surveillance in non-human primates (Alouatta caraya) in southern Brazil. J. Med. Primatol. 2019, 48, 211-217. [CrossRef]

262. Pereira, L.E.; Suzuki, A.; Coimbra, T.L.M.; Souza, R.P.d.; Chamelet, E.L.B. Arbovírus Ilheus em aves silvestres (Sporophila caerulescens e Molothrus bonariensis). Rev. Saude Publica 2001, 35, 119-123. [CrossRef] [PubMed]

263. Svoboda, W.K.; Martins, L.C.; Malanski Lde, S.; Shiozawa, M.M.; Spohr, K.A.; Hilst, C.L.; Aguiar, L.M.; Ludwig, G.; Passos Fde, C.; Silva, L.R.; et al. Serological evidence for Saint Louis encephalitis virus in free-ranging New World monkeys and horses within the upper Parana River basin region, Southern Brazil. Rev. Soc. Bras. Med. Trop. 2014, 47, 280-286. [CrossRef]

264. Terzian, A.C.B.; Zini, N.; Sacchetto, L.; Rocha, R.F.; Parra, M.C.P.; Del Sarto, J.L.; Dias, A.C.F.; Coutinho, F.; Rayra, J.; da Silva, R.A.; et al. Evidence of natural Zika virus infection in neotropical non-human primates in Brazil. Sci. Rep. 2018, 8, 16034. [CrossRef] [PubMed]

265. Moreira, G.V.; Peixoto, C.M.S.; Ziccardi, M.; Oliveira, R.L.; Castro, M.G.; Dionísio, D.F.; Pissinatti, A. Prevalência de Trypanosoma cruzi, Trypanosoma minasense e de anticorpos contra arbovírus em primatas não humanos (Callithrichidae) em cativeiro. Rev. Bras. Med. Vet. 2000, 22, 252-254.

266. Carvalho, V.L.; Nunes, M.R.T.; Medeiros, D.B.A.; da Silva, S.P.; Lima, C.P.S.; Inada, D.T.; Cardoso, J.F.; Vianez, J.L.S.G.; Rodrigues, S.G.; Vasconcelos, P.F.C. New Virus Genome Sequences of the Guama Serogroup (Genus Orthobunyavirus, Family Bunyaviridae), Isolated in the Brazilian Amazon Region. Genome Announc. 2017, 5, e01750-01716. [CrossRef] [PubMed]

267. Gibrail, M.M.; Fiaccadori, F.S.; Souza, M.; Almeida, T.N.V.; Chiang, J.O.; Martins, L.C.; Ferreira, M.S.; de Paula Cardoso, D.d.D. Detection of antibodies to Oropouche virus in non-human primates in Goiânia City, Goiás. Rev. Soc. Bras. Med. Trop. 2016, 49, 357-360. [CrossRef]

268. Nunes, M.R.T.; Martins, L.C.; Rodrigues, S.G.; Chiang, J.O.; Azevedo, R.d.S.d.S.; da Rosa, A.P.A.T.; Vasconcelos, P.F.d.C. Oropouche virus isolation, southeast Brazil. Emerg. Infect. Dis. 2005, 11, 1610-1613. [CrossRef]

269. Oliveira, D.B.; Luiz, A.P.; Fagundes, A.; Pinto, C.A.; Bonjardim, C.A.; Trindade, G.S.; Kroon, E.G.; Abrahao, J.S.; Ferreira, P.C. Evidence of Apeu Virus Infection in Wild Monkeys, Brazilian Amazon. Am. J. Trop. Med. Hyg. 2016, 94, 494-496. [CrossRef] [PubMed]

270. Pedersen, A.; Davies, T. Cross-Species Pathogen Transmission and Disease Emergence in Primates. EcoHealth 2009, 6, 496-508. [CrossRef]

271. Slingenbergh, J.I.; Gilbert, M.; de Balogh, K.I.; Wint, W. Ecological sources of zoonotic diseases. Rev. Sci Tech. 2004, 23, 467-484. [CrossRef]

272. Rushmore, J.; Bisanzio, D.; Gillespie, T.R. Making New Connections: Insights from Primate-Parasite Networks. Trends. Parasitol. 2017, 33, 547-560. [CrossRef]

273. Altizer, S.; Nunn, C.L.; Thrall, P.H.; Gittleman, J.L.; Antonovics, J.; Cunningham, A.A.; Dobson, A.P.; Ezenwa, V.; Jones, K.E.; Pedersen, A.B.; et al. Social organization and disease risk in mammals: Integrating theory and empirical studies. Annu. Rev. Ecol. Syst. 2003, 34, 517-547. [CrossRef]

274. Daviews, C.R.; Ayres, J.M.; Dye, C.; Deane, L.M. Malaria Infection Rate of Amazonian Primates Increases with Body Weight and Group Size. Funct. Ecol. 1991, 5, 655-662. [CrossRef]

275. Nunn, C.L.; Heymann, E.W. Malaria infection and host behavior: A comparative study of Neotropical primates. Behav.Ecol. Soc. 2005, 59, 30-37. [CrossRef]

276. Côté, I.M.; Poulin, R. Parasitism and group size in social animals: A meta-analysis. Behav. Ecol. 1995, 6, 159-165. [CrossRef]

277. Nunn, C.L.; Jordán, F.; McCabe, C.M.; Verdolin, J.L.; Fewell, J.H. Infectious disease and group size: More than just a numbers game. Philos. Trans. R. Soc. Lond. B Biol. Sci. 2015, 370, 20140111. [CrossRef] [PubMed]

278. Akinyi, M.Y.; Tung, J.; Jeneby, M.; Patel, N.B.; Altmann, J.; Alberts, S.C. Role of Grooming in Reducing Tick Load in Wild Baboons (Papio cynocephalus). Anim. Behav. 2013, 85, 559-568. [CrossRef]

279. Duboscq, J.; Romano, V.; Sueur, C.; MacIntosh, A.J.J. Network centrality and seasonality interact to predict lice load in a social primate. Sci. Rep. 2016, 6, 22095. [CrossRef] 
280. Zohdy, S.; Kemp, A.D.; Durden, L.A.; Wright, P.C.; Jernvall, J. Mapping the social network: Tracking lice in a wild primate (Microcebus rufus) population to infer social contacts and vector potential. BMC ECOL 2012, 12, 4. [CrossRef] [PubMed]

281. Roux, V.; Raoult, D. Body lice as tools for diagnosis and surveillance of reemerging diseases. J. Clin. Microbiol. 1999, 37, 596-599. [CrossRef] [PubMed]

282. Hornok, S.; Hofmann-Lehmann, R.; de Mera, I.G.; Meli, M.L.; Elek, V.; Hajtos, I.; Repasi, A.; Gonczi, E.; Tanczos, B.; Farkas, R.; et al. Survey on blood-sucking lice (Phthiraptera: Anoplura) of ruminants and pigs with molecular detection of Anaplasma and Rickettsia spp. Vet. Parasitol 2010, 174, 355-358. [CrossRef] [PubMed]

283. De Nys, H.M.; Calvignac-Spencer, S.; Thiesen, U.; Boesch, C.; Wittig, R.M.; Mundry, R.; Leendertz, F.H. Age-related effects on malaria parasite infection in wild chimpanzees. Biol. Lett. 2013, 9, 20121160. [CrossRef]

284. Frölich, S.; Entzeroth, R.; Wallach, M. Comparison of protective immune responses to apicomplexan parasites. J. Parasitol. Res. 2012, 2012, 852591. [CrossRef]

285. Springer, A.; Fichtel, C.; Calvignac-Spencer, S.; Leendertz, F.H.; Kappeler, P.M. Hemoparasites in a wild primate: Infection patterns suggest interaction of Plasmodium and Babesia in a lemur species. Int. J. Parasitol. Parasites Wildl. 2015, 4, 385-395. [CrossRef]

286. Hokan, M.; Strube, C.; Radespiel, U.; Zimmermann, E. Sleeping site ecology, but not sex, affect ecto- and hemoparasite risk, in sympatric, arboreal primates (Avahi occidentalis and Lepilemur edwardsi). Front. Zool. 2017, 14, 44. [CrossRef] [PubMed]

287. Samson, D.R.; Muehlenbein, M.P.; Hunt, K.D. Do chimpanzees (Pan troglodytes schweinfurthii) exhibit sleep related behaviors that minimize exposure to parasitic arthropods? A preliminary report on the possible anti-vector function of chimpanzee sleeping platforms. Primates 2013, 54, 73-80. [CrossRef]

288. Morales, M.A.; Barrandeguy, M.; Fabbri, C.; Garcia, J.B.; Vissani, A.; Trono, K.; Gutierrez, G.; Pigretti, S.; Menchaca, H.; Garrido, N.; et al. West Nile virus isolation from equines in Argentina, 2006. Emerg. Infect. Dis. 2006, 12, 1559-1561. [CrossRef]

289. Pinto, J.; Bonacic, C.; Hamilton-West, C.; Romero, J.; Lubroth, J. Climate change and animal diseases in South America. Rev. Sci Tech. 2008, 27, 599-613.

290. Reed, K.D.; Meece, J.K.; Henkel, J.S.; Shukla, S.K. Birds, migration and emerging zoonoses: West nile virus, lyme disease, influenza A and enteropathogens. Clin. Med. Res. 2003, 1, 5-12. [CrossRef]

291. Seidowski, D.; Ziegler, U.; von Ronn, J.A.; Muller, K.; Huppop, K.; Muller, T.; Freuling, C.; Muhle, R.U.; Nowotny, N.; Ulrich, R.G.; et al. West Nile virus monitoring of migratory and resident birds in Germany. Vector Borne Zoonotic Dis. 2010, 10, 639-647. [CrossRef]

292. Altizer, S.; Bartel, R.; Han, B.A. Animal Migration and Infectious Disease Risk. Science 2011, 331, 296. [CrossRef] [PubMed]

293. Wilson, M.E. Travel and the Emergence of Infectious Diseases. Emerg. Infect. Dis. 1995, 1, 39-46. [CrossRef]

294. Rodrigues, P.T.; Valdivia, H.O.; de Oliveira, T.C.; Alves, J.M.P.; Duarte, A.M.R.C.; Cerutti-Junior, C.; Buery, J.C.; Brito, C.F.A.; de Souza, J.C.; Hirano, Z.M.B.; et al. Human migration and the spread of malaria parasites to the New World. Sci. Rep. 2018, 8, 1993. [CrossRef]

295. Gómez, J.M.; Nunn, C.L.; Verdú, M. Centrality in primate-parasite networks reveals the potential for the transmission of emerging infectious diseases to humans. Proc. Natl. Acad. Sci. USA 2013, 110, 7738-7741. [CrossRef]

296. Candeloro, L.; Savini, L.; Conte, A. A New Weighted Degree Centrality Measure: The Application in an Animal Disease Epidemic. PLoS ONE 2016, 11, e0165781. [CrossRef]

297. Peters, W.; Garnham, P.C.C.; Killick-Kendrick, R.; Rajapaksa, N.; Cheong, W.H.; Cadigan, F.C. Malaria of the orang-utan (Pongo pygmaeus) in Borneo. Philos. Trans. R. Soc. Lond. B Biol. Sci. 1976, 275, 439-482. [CrossRef]

298. Harvell, C.D.; Kim, K.; Burkholder, J.M.; Colwell, R.R.; Epstein, P.R.; Grimes, D.J.; Hofmann, E.E.; Lipp, E.K.; Osterhaus, A.D.M.E.; Overstreet, R.M.; et al. Emerging Marine Diseases_Climate Links and Anthropogenic Factors. Science 1999, 285, 1505. [CrossRef]

299. Behie, A.M.; Kutz, S.; Pavelka, M.S. Cascading Effects of Climate Change: Do Hurricane-damaged Forests Increase Risk of Exposure to Parasites? Biotropica 2014, 46, 25-31. [CrossRef]

300. Lawler, J.J.; Shafer, S.L.; White, D.; Kareiva, P.; Maurer, E.P.; Blaustein, A.R.; Bartlein, P.J. Projected climate-induced faunal change in the Western Hemisphere. Ecology 2009, 90, 588-597. [CrossRef]

301. Dunbar, R.I.M. Impact of global warming on the distribution and survival of the gelada baboon: A modelling approach. Glob. Chang. Biol. 1998, 4, 293-304. [CrossRef]

302. Colwell, R.K.; Brehm, G.; Cardelús, C.L.; Gilman, A.C.; Longino, J.T. Global Warming, Elevational Range Shifts, and Lowland Biotic Attrition in the Wet Tropics. Science 2008, 322, 258. [CrossRef] [PubMed]

303. Luo, Z.; Zhou, S.; Yu, W.; Yu, H.; Yang, J.; Tian, Y.; Zhao, M.; Wu, H. Impacts of climate change on the distribution of Sichuan snub-nosed monkeys (Rhinopithecus roxellana) in Shennongjia area, China. Am. J. Primatol. 2015, 77, 135-151. [CrossRef] [PubMed]

304. Nunn, C.L.; Altizer, S.; Sechrest, W.; Cunningham, A.A. Latitudinal gradients of parasite species richness in primates. Divers. Distrib. 2005, 11, 249-256. [CrossRef]

305. IPCC. Climate Change 2013: The Physical Science Basis. Contribution of Working Group I to the Fifth Assessment Report of the Intergovernmental Panel on Climate Change; Cambridge University Press: Cambridge, UK; New York, NY, USA, 2013 ; p. 1535.

306. Wright, P.C.; Arrigo-Nelson, S.J.; Hogg, K.L.; Bannon, B.; Morelli, T.L.; Wyatt, J.; Harivelo, A.L.; Ratelolahy, F. Habitat disturbance and seasonal fluctuations of lemur parasites in the rain forest of Ranomafana National Park, Madagascar. In Primate Parasite Ecology: The Dynamics and Study of Host-Parasite Relationships; Chapman, C.A., Huffman, M.A., Eds.; Cambridge University Press: Cambridge, UK, 2009; pp. 311-330. 
307. Bezjian, M.; Gillespie, T.R.; Chapman, C.A.; Greiner, E.C. Coprologic evidence of gastrointestinal helminths of Forest baboons, Papio anubis, in Kibale National Park, Uganda. J. Wildl. Dis. 2008, 44, 878-887. [CrossRef]

308. Goldberg, T.L.; Gillespie, T.R.; Rwego, I.B.; Estoff, E.E.; Chapman, C. Forest fragmentation as cause of bacterial transmission among primates, humans, and livestock, Uganda. Emerg. Infect. Dis. 2008, 14, 1375-1382. [CrossRef] [PubMed]

309. Gao, D.; van den Driessche, P.; Cosner, C. Habitat fragmentation promotes malaria persistence. J. Math. Biol. 2019, 79, 2255-2280. [CrossRef] [PubMed]

310. Garamszegi, L.Z. Patterns of co-speciation and host switching in primate malaria parasites. Malar. J. 2009, 8, 110. [CrossRef]

311. Akpan, G.E.; Adepoju, K.A.; Oladosu, O.R. Potential distribution of dominant malaria vector species in tropical region under climate change scenarios. PLoS ONE 2019, 14, e0218523. [CrossRef]

312. Githeko, A.K.; Lindsay, S.W.; Confalonieri, U.E.; Patz, J.A. Climate change and vector-borne diseases: A regional analysis. Bull. World Health Organ. 2000, 78, 1136-1147.

313. Mills, J.N.; Gage, K.L.; Khan, A.S. Potential Influence of Climate Change on Vector-Borne and Zoonotic Diseases: A Review and Proposed Research Plan. Environ. Health Perspect. 2010, 118, 1507-1514. [CrossRef]

314. Leal Filho, W.; Bönecke, J.; Spielmann, H.; Azeiteiro, U.M.; Alves, F.; Lopes de Carvalho, M.; Nagy, G.J. Climate change and health: An analysis of causal relations on the spread of vector-borne diseases in Brazil. J. Clean. Prod. 2018, 177, 589-596. [CrossRef]

315. Rodriguez, I.A.; Rasoazanabary, E.; Godfrey, L.R. Seasonal variation in the abundance and distribution of ticks that parasitize Microcebus griseorufus at the Bezà Mahafaly Special Reserve, Madagascar. Int. J. Parasitol. Parasites Wildl. 2015, 4, 408-413. [CrossRef] [PubMed]

316. Fecchio, A.; Wells, K.; Bell, J.A.; Tkach, V.V.; Lutz, H.L.; Weckstein, J.D.; Clegg, S.M.; Clark, N.J. Climate variation influences host specificity in avian malaria parasites. Ecol. Lett. 2019, 22, 547-557. [CrossRef]

317. Waikhom, P.; Jain, R.; Tegar, S. Pathogen adaptation to temperature with density dependent host mortality and climate change. Model. Earth Syst. Environ. 2019, 5, 709-724. [CrossRef]

318. Visser, M.E.; Both, C. Shifts in phenology due to global climate change: The need for a yardstick. Proc. Biol. Sci. 2005, 272, 2561-2569. [CrossRef]

319. Fan, P.-F.; Jiang, X.-L. Effects of food and topography on ranging behavior of black crested gibbon (Nomascus concolor jingdongensis) in Wuliang Mountain, Yunnan, China. Am. J. Primatol. 2008, 70, 871-878. [CrossRef]

320. Garber, P. Seasonal patterns of diet and ranging in two species of tamarin monkeys: Stability versus variability. Int. J. Primatol. 1993, 14, 145-166. [CrossRef]

321. Hill, R.A.; Dunbar, R.I.M. Climatic determinants of diet and foraging behaviour in baboons. Evol. Ecol. $2002,16,579-593$.

322. Yamagiwa, J. Socioecological factors influencing population structure of gorillas and chimpanzees. Primates 1999, 40, 87-104. [CrossRef] [PubMed]

323. Hoberg, E.P.; Brooks, D.R. Evolution in action: Climate change, biodiversity dynamics and emerging infectious disease. Philos. Trans. R. Soc. Lond. B Biol. Sci. 2015, 370, 20130553. [CrossRef] [PubMed]

324. Sibley, L.D.; Khan, A.; Ajioka, J.W.; Rosenthal, B.M. Genetic diversity of Toxoplasma gondii in animals and humans. Philos. Trans. R. Soc. B 2009, 364, 2749-2761. [CrossRef]

325. Davidson, G.; Chua, T.H.; Cook, A.; Speldewinde, P.; Weinstein, P. The Role of Ecological Linkage Mechanisms in Plasmodium knowlesi Transmission and Spread. EcoHealth 1039, -6. [CrossRef] [PubMed]

326. Gould, E.; Pettersson, J.; Higgs, S.; Charrel, R.; de Lamballerie, X. Emerging arboviruses: Why today? One Health 2017, 4, 1-13. [CrossRef]

327. Failloux, A.-B. Human activities and climate change in the emergence of vector-borne diseases. C. R. Biol. 2019, 342, 269-270. [CrossRef]

328. Lafferty, K.D.; Holt, R.D. How should environmental stress affect the population dynamics of disease? Ecol. Lett. 2003. [CrossRef]

329. Coop, R.L.; Kyriazakis, I. Nutrition-parasite interaction. Vet. Parasitol. 1999, 84, 187-204. [CrossRef]

330. OIE. Chapter 3.9.11.-Zoonoses Transmissible from Non-Human Primates; OIE: Paris, France, 2019.

331. OIE. OIE-Listed Diseases, Infections and Infestations in Force in 2020. Available online: https://www.oie.int/en/animal-healthin-the-world/oie-listed-diseases-2020/ (accessed on 25 February 2021).

332. OIE. Ebola Virus Disease. Available online: https://www.oie.int/en/animal-health-in-the-world/animal-diseases/Ebola-virusdisease/ (accessed on 25 February 2021).

333. OIE. Guidelines for Wildlife Disease Surveillance: An Overview; OIE: Paris, France, 2015; p. 8.

334. OIE. Training Manual on Wildlife Diseases and Surveillance: Workshop for OIE National Focal Points for Wildlife; OIE: Paris, France, 2010.

335. IUCN. Workshop to Develop a Wildlife Health Plan for the Galápagos Islands; Wildlife Conservation Society: New York, NY, USA, 2015.

336. Jakob-Hoff, R.M.; MacDiarmid, S.C.; Lees, C.; Miller, P.S.; Travis, D.; Kock, R. Manual of Procedures for Wildlife Disease Risk Analysis; IUCN: Paris, France, 2014; p. 143.

337. Ahmed, S.; Sarowar Alam, A.B.M.; Azmiri, K.; ZenifarRahman, M.Z. A Field Manual for the Study of Wild Birds: Bird Census, Bird Ringing, Sample Collection and Analysis; IUCN: Dhaka, Bangladesh, 2015; p. 60.

338. IUCN. Guidelines for Wildlife Disease Risk Analysis; OIE: Paris, France, 2014; p. 24.

339. MinistériodaSaúde. Manual de vigilância de epizootias em primatas não-humanos; Ministério da Saúde: Brasilia, Brazil, $2005 ; \mathrm{p} .58$.

340. MinistériodaSaúde. Guia de vigilância de epizootias em primatas não humanos e entomologia aplicada à vigilância da febre amarela; Ministério da Saúde: Brasilia, Brazil, 2014. 
341. da Rocha, T.C.; Batista, P.M.; Andreotti, R.; Bona, A.C.D.; da Silva, M.A.N.; Lange, R.; Svoboda, W.K.; Gomes, E.C. Evaluation of arboviruses of public health interest in free-living non-human primates (Alouatta spp., Callithrix spp., Sapajus spp.) in Brazil. Rev. Soc. Bras. Med. Trop. 2015, 48, 143-148. [CrossRef] [PubMed]

342. Brasil, P.; Zalis, M.G.; de Pina-Costa, A.; Siqueira, A.M.; Junior, C.B.; Silva, S.; Areas, A.L.L.; Pelajo-Machado, M.; de Alvarenga, D.A.M.; da Silva Santelli, A.C.F.; et al. Outbreak of human malaria caused by Plasmodium simium in the Atlantic Forest in Rio de Janeiro: A molecular epidemiological investigation. Lancet Glob. Health 2017, 5, e1038-e1046. [CrossRef]

343. Almeida, M.A.B.; Cardoso, J.d.C.; dos Santos, E.; da Fonseca, D.F.; Cruz, L.L.; Faraco, F.J.C.; Bercini, M.A.; Vettorello, K.C.; Porto, M.A.; Mohrdieck, R.; et al. Surveillance for Yellow Fever Virus in Non-Human Primates in Southern Brazil, 2001-2011: A Tool for Prioritizing Human Populations for Vaccination. PLoS Negl. Trop. Dis. 2014, 8, e2741. [CrossRef]

344. Althouse, B.M.; Guerbois, M.; Cummings, D.A.T.; Diop, O.M.; Faye, O.; Faye, A.; Diallo, D.; Sadio, B.D.; Sow, A.; Faye, O.; et al. Role of monkeys in the sylvatic cycle of chikungunya virus in Senegal. Nat. Commun. 2018, 9, 1046. [CrossRef]

345. Liu, Q.; Wang, Z.-D.; Huang, S.-Y.; Zhu, X.-Q. Diagnosis of toxoplasmosis and typing of Toxoplasma gondii. Parasit Vectors 2015, 8, 292. [CrossRef]

346. Liu, W.; Sherrill-Mix, S.; Learn, G.H.; Scully, E.J.; Li, Y.; Avitto, A.N.; Loy, D.E.; Lauder, A.P.; Sundararaman, S.A.; Plenderleith, L.J.; et al. Wild bonobos host geographically restricted malaria parasites including a putative new Laverania species. Nat. Commun. 2017, 8, 1635. [CrossRef] [PubMed]

347. Milich, K.M.; Koestler, B.J.; Simmons, J.H.; Nehete, P.N.; Di Fiore, A.; Williams, L.E.; Dudley, J.P.; Vanchiere, J.; Payne, S.M. Methods for detecting Zika virus in feces: A case study in captive squirrel monkeys (Saimiri boliviensis boliviensis). PLoS ONE 2018, 13, e0209391. [CrossRef] [PubMed]

348. Abkallo, H.M.; Liu, W.; Hokama, S.; Ferreira, P.E.; Nakazawa, S.; Maeno, Y.; Quang, N.T.; Kobayashi, N.; Kaneko, O.; Huffman, M.A.; et al. DNA from pre-erythrocytic stage malaria parasites is detectable by PCR in the faeces and blood of hosts. Int. J. Parasitol. 2014, 44, 467-473. [CrossRef]

349. Lloyd, Y.M.; Esemu, L.F.; Antallan, J.; Thomas, B.; Tassi Yunga, S.; Obase, B.; Christine, N.; Leke, R.G.F.; Culleton, R.; Mfuh, K.O.; et al. PCR-based detection of Plasmodium falciparum in saliva using mitochondrial cox3 and varATS primers. Trop. Med. Health. 2018, 46, 22. [CrossRef]

350. Mfuh, K.O.; Tassi Yunga, S.; Esemu, L.F.; Bekindaka, O.N.; Yonga, J.; Djontu, J.C.; Mbakop, C.D.; Taylor, D.W.; Nerurkar, V.R.; Leke, R.G.F. Detection of Plasmodium falciparum DNA in saliva samples stored at room temperature: Potential for a non-invasive saliva-based diagnostic test for malaria. Malar. J. 2017, 16, 434. [CrossRef] [PubMed]

351. Wedrowicz, F.; Saxton, T.; Mosse, J.; Wright, W.; Hogan, F.E. A non-invasive tool for assessing pathogen prevalence in koala (Phascolarctos cinereus) populations: Detection of Chlamydia pecorum and koala retrovirus (KoRV) DNA in genetic material sourced from scats. Conserv. Genet. Resour. 2016, 8, 511-521. [CrossRef]

352. Hofmann, N.; Mwingira, F.; Shekalaghe, S.; Robinson, L.J.; Mueller, I.; Felger, I. Ultra-Sensitive Detection of Plasmodium falciparum by Amplification of Multi-Copy Subtelomeric Targets. PLoS Med. 2015, 12, e1001788. [CrossRef]

353. Grabias, B.; Essuman, E.; Quakyi, I.A.; Kumar, S. Sensitive real-time PCR detection of Plasmodium falciparum parasites in whole blood by erythrocyte membrane protein 1 gene amplification. Malar. J. 2019, 18, 116. [CrossRef] [PubMed]

354. Nederhand, R.J.; Droog, S.; Kluft, C.; Simoons, M.L.; de Maat, M.P. Logistics and quality control for DNA sampling in large multicenter studies. J. Thromb. Haemost. 2003, 1, 987-991. [CrossRef]

355. Schwartz, A.; Baidjoe, A.; Rosenthal, P.J.; Dorsey, G.; Bousema, T.; Greenhouse, B. The Effect of Storage and Extraction Methods on Amplification of Plasmodium falciparum DNA from Dried Blood Spots. Am. J. Trop. Med. Hyg. 2015, 92, 922-925. [CrossRef]

356. Canier, L.; Khim, N.; Kim, S.; Eam, R.; Khean, C.; Loch, K.; Ken, M.; Pannus, P.; Bosman, P.; Stassijns, J.; et al. Malaria PCR Detection in Cambodian Low-Transmission Settings: Dried Blood Spots Versus Venous Blood Samples. Am. J. Trop. Med. Hyg. 2015, 92, 573-577. [CrossRef]

357. Tran, T.M.; Aghili, A.; Li, S.; Ongoiba, A.; Kayentao, K.; Doumbo, S.; Traore, B.; Crompton, P.D. A nested real-time PCR assay for the quantification of Plasmodium falciparum DNA extracted from dried blood spots. Malar. J. 2014, 13, 393. [CrossRef]

358. Mahajan, B.; Zheng, H.; Pham, P.T.; Sedegah, M.Y.; Majam, V.F.; Akolkar, N.; Rios, M.; Ankrah, I.; Madjitey, P.; Amoah, G.; et al. Polymerase chain reaction-based tests for pan-species and species-specific detection of human Plasmodium parasites. Transfusion 2012, 52, 1949-1956. [CrossRef]

359. Ghindilis, A.L.; Chesnokov, O.; Ngasala, B.; Smith, M.W.; Smith, K.; Mårtensson, A.; Oleinikov, A.V. Detection of sub-microscopic blood levels of Plasmodium falciparum using Tandem Oligonucleotide Repeat Cascade Amplification (TORCA) assay with an attomolar detection limit. Sci. Rep. 2019, 9, 2901. [CrossRef]

360. Lederberg, J.; Shope, R.E.; Oaks, S.C., Jr. Emerging Infections: Microbial Threats to Health in the United States; Lederberg, J., Shope, R.E., Oaks, S.C., Jr., Eds.; National Academy of Sciences: Washington, DC, USA, 1992. [CrossRef]

361. Rascalou, G.; Pontier, D.; Menu, F.; Gourbière, S. Emergence and prevalence of human vector-borne diseases in sink vector populations. PLoS ONE 2012, 7, e36858. [CrossRef]

362. Simpson, J.E.; Hurtado, P.J.; Medlock, J.; Molaei, G.; Andreadis, T.G.; Galvani, A.P.; Diuk-Wasser, M.A. Vector host-feeding preferences drive transmission of multi-host pathogens: West Nile virus as a model system. Proc. Royal Soc. B 2012, 279, 925-933. [CrossRef]

363. Caja Rivera, R.M. How vector feeding preference through an infectious host relates to the seasonal transmission rates in a mathematical vector-host model. Math. Methods Appl. Sci. 2019, 42, 6810-6828. [CrossRef] 
364. Rondón, S.; León, C.; Link, A.; González, C. Prevalence of Plasmodium parasites in non-human primates and mosquitoes in areas with different degrees of fragmentation in Colombia. Malar. J. 2019, 18, 276. [CrossRef] [PubMed]

365. Piel, A.K.; Lenoel, A.; Johnson, C.; Stewart, F.A. Deterring poaching in western Tanzania: The presence of wildlife researchers. Glob. Ecol. Conserv. 2015, 3, 188-199. [CrossRef]

366. Oklander, L.I.; Caputo, M.; Solari, A.; Corach, D. Genetic assignment of illegally trafficked neotropical primates and implications for reintroduction programs. Sci. Rep. 2020, 10, 3676. [CrossRef]

367. Messenger, A.M.; Barnes, A.N.; Gray, G.C. Reverse zoonotic disease transmission (zooanthroponosis): A systematic review of seldom-documented human biological threats to animals. PLOS ONE 2014. [CrossRef]

368. Lambert, C.; Couteaudier, M.; Gouzil, J.; Richard, L.; Montange, T.; Betsem, E.; Rua, R.; Tobaly-Tapiero, J.; Lindemann, D.; Njouom, R.; et al. Potent neutralizing antibodies in humans infected with zoonotic simian foamy viruses target conserved epitopes located in the dimorphic domain of the surface envelope protein. PLoS Pathog. 2018, 14, e1007293. [CrossRef]

369. Cunningham, A. Disease Risks of Wildlife Translocations. Conserv. Biol. 1996, 10, 349-353. [CrossRef]

370. IUCN/SSC. Guidelines for Reintroductions and Other Conservation Translocations. Version 1.0. IUCN Species Survival Commission, Gland, Switzerland. Available online: http:/ /www.issg.org/pdf/publications/RSG_ISSG-Reintroduction-Guidelines-2013 .pdf (accessed on 20 February 2021).

371. Hollingsworth, P.; Gaywood, M. New international and national guidelines for conservation translocations. Practice 2015, 89, 8-10.

372. Liberati, A.; Altman, D.G.; Tetzlaff, J.; Mulrow, C.; Gøtzsche, P.C.; Ioannidis, J.P.A.; Clarke, M.; Devereaux, P.J.; Kleijnen, J.; Moher, D. The PRISMA Statement for Reporting Systematic Reviews and Meta-Analyses of Studies That Evaluate Health Care Interventions: Explanation and Elaboration. PLoS Med. 2009, 6, e1000100. [CrossRef] [PubMed]

373. Moher, D.; Liberati, A.; Tetzlaff, J.; Altman, D. Preferred Reporting Items for Systematic Reviews and MetaAnalyses: The PRISMA Statement. PLoS Med. 2009, 6, e1000097. [CrossRef]

374. Muehlenbein, M.P.; Ancrenaz, M. Minimizing pathogen transmission at primate ecotourism destinations: The need for input from travel medicine. J. Travel Med. 2009, 16, 229-232. [CrossRef] [PubMed]

375. Muehlenbein, M.P. Primates on display: Potential disease consequences beyond bushmeat. Am. J. Phys. Anthropol. 2017, 162, 32-43. [CrossRef] [PubMed]

376. Carne, C.; Semple, S.; MacLarnon, A.; Majolo, B.; Maréchal, L. Implications of Tourist-Macaque Interactions for Disease Transmission. EcoHealth 2017, 14, 704-717. [CrossRef]

377. Devaux, C.A.; Mediannikov, O.; Medkour, H.; Raoult, D. Infectious Disease Risk Across the Growing Human-Non Human Primate Interface: A Review of the Evidence. Front. Public Health. 2019, 7, 305. [CrossRef]

378. Pedersen, K.; Baroch, J.; Nolte, D.; Gidlewski, T.; Deliberto, T. The Role of the National Wildlife Disease Program. In Wildlife Disease Surveillance and Emergency Response; USDA National Wildlife Research Center-Staff Publications: Fort Collins, CO, USA, 2012.

379. Guberti, V.; Stancampiano, L.; Ferrari, N. Surveillance, monitoring and surveys of wildlife diseases: A public health and conservation approach. Hystrix It. J. Mamm. 2014, 25, 3-8. [CrossRef]

380. Pedersen, A.B.; Jones, K.E.; Nunn, C.L.; Altizer, S. Infectious diseases and extinction risk in wild animals. Conserv. Biol. 2007, 21, 1269-1279. [CrossRef]

381. Holmes, J.P.; Duff, J.P.; Barlow, A.; Everest, D.; Man, C.; Smith, F.; Twomey, F. 20 years of national wildlife disease surveillance. Vet. Rec. 2019, 184, 520. [CrossRef] [PubMed]

382. Woods, R.; Reiss, A.; Cox-Witton, K.; Grillo, T.; Peters, A. The Importance of Wildlife Disease Monitoring as Part of Global Surveillance for Zoonotic Diseases: The Role of Australia. Trop. Med. Infect. Dis. 2019, 4, 29. [CrossRef] [PubMed]

383. Mörner, T.; Obendorf, D.; Artois, M.; Woodford, M. Surveillance and monitoring of wildlife diseases. Rev. Sci Tech. 2002, 21, 67-76. [CrossRef] [PubMed]

384. Vrbova, L.; Stephen, C.; Kasman, N.; Boehnke, R.; Doyle-Waters, M.; Chablitt-Clark, A.; Gibson, B.; FitzGerald, M.; Patrick, D.M. Systematic review of surveillance systems for emerging zoonoses. Trans. Emerg. Dis. 2010, 57, 154-161. [CrossRef] [PubMed] 